\title{
30
}

\section{Defences to Criminal Liability}

\author{
SARA WHARTON
}

\section{INTRODUCTION}

Defences to criminal liability have played a very limited role in the existing jurisprudence of the contemporary international criminal courts and tribunals. ${ }^{1}$ In fact, they have been described as 'an oft-forgotten aspect of international criminal law'. ${ }^{2}$ This is likely due in part to the fact that the existing international criminal courts and tribunals prosecute only a small number of potential perpetrators. The selectivity exercised by the prosecutor limits the cases pursued to those individuals who are most responsible and against whom the prosecutors have the strongest case. This likely excludes those cases where there may be a strong defence which would exclude criminal culpability. ${ }^{3}$ It has also been suggested that the lack of attention may also be due to 'a lack of sympathy' for the accused. ${ }^{4}$ However, all criminal trials, including for the gravest international or transnational crimes, must be conducted in full

1 This chapter will use the broad term 'defences' rather than the civil law division between justification or excuses, or the language adopted at the International Criminal Court of 'grounds for excluding criminal responsibility', to refer to all substantive defences other than simply putting the Prosecutor's burden of proof to the test. For other sources on defences in international criminal law see: G.J.A. Knoops, Defenses in Contemporary International Criminal Law, (2nd edn., Leiden: Martinus Nijhoff, 2008); A. Cassese, International Criminal Law, (2nd edn., Oxford: Oxford University Press, 2008) at 255-301; R. Cryer et al., An Introduction to International Criminal Law and Procedure, (3rd edn. Cambridge: Cambridge University Press, 2014) at 398-418; I. Bantekas, International Criminal Law, (4th ed. Oxford: Hart Publishing, 2010) at 99-121; Y. Dinstein, 'International Criminal Courts and Tribunals, Defences', Max Planck Encyclopedia of Public International Law available online: http://opil .ouplaw.com/home/EPIL.

Cryer et al., ibid., at 398 .

3 Ibid.

4 Ibid. 
accordance with general principles of criminal law including all accepted grounds for excluding criminal responsibility.

The Draft Protocol on Amendments to the Protocol on the Statute of the African Court of Justice and Human Rights (the Malabo Protocol) does not include a provision defining which defences will be applicable before the African Court of Justice and Human Rights (the African Court). This is not unusual. Other contemporary international criminal institutions are similarly predominantly silent on the question of defences, including the statutes of the International Criminal Tribunal for the former Yugoslavia (ICTY) and the International Criminal Tribunal for Rwanda (ICTR). ${ }^{5}$ This silence, of course, does not infer the irrelevance of defences. As noted by the ICTY Trial Chamber, defences 'form part of the general principles of criminal law which the International Tribunal must take into account in deciding the case before it. ${ }^{6}$ The Court will, therefore, need to turn to customary international law and to general principles of law to determine and to define applicable defences. ${ }^{7}$ The Court will also have to consider whether it will permit resort to domestic laws of African or other states as a possible default when no customary international law or general principle can be found.

It is beyond the scope of this chapter to conduct a comparative analysis of domestic laws to determine which general principles and regional norms prevail. This is a task that the African Court itself will have to undertake on a case-by-case basis as arguments about defences are brought before it. Nonetheless, caution should be exercised if such borrowing is found necessary. For one thing, even in the continent of Africa, there may be different understandings of defences to liability based on the underlying origins of the municipal legal system in question. For example, the approach to particular defences might differ between and among common law or civil law jurisdictions and others that might be more appropriately considered mixed jurisdictions. This chapter has the more limited task of examining the existing body of international criminal law to see what guidance the African Court may take with respect to which defences have been recognized and which have been explicitly rejected, how recognized defences have been defined, and what questions have arisen or may arise with respect to these defences.

5 These statutes do explicitly exclude the defence of superior orders as a ground of excluding criminal responsibility (as discussed below).

6 Judgment, Prosecutor v. Dario Kordić and Mario Čerkez, (IT-95-14/2-T), Trial Chamber, 26 February 2001, para. 449 ('Kordić and Čerkez Trial Judgment').

7 In line with the sources of international law delineated in Article 38(1)(b) and (c) of the Statute of the International Court of Justice, annexed to the Charter of the United Nations, San Francisco, 24 October 1945 . 
As the African Court starts to exercise its criminal jurisdiction, in addition to the recognition and definition of defences, the court will also need to consider and define the evidentiary and procedural rules that will be applicable. ${ }^{8}$ For example, what, if any, burden lies on the accused to establish certain defences? What disclosure obligations does the defence have should it seek to raise such a defence? Some of these issues would be better suited for resolution in the rules of procedure and evidence of the future court.

Turning to the existing body of international criminal law, a starting point is to look historically to the report of the United Nations War Crimes Commission (UNWCC) which collected judicial decisions of numerous war crimes trials conducted after World War II by multiple countries with the aim of 'deriv[ing] from the records in the possession of the Commission all material containing any guidance for the building up of a jurisprudence of war crimes law'. 9 This report gives some guidance as to which defences were raised, which defences were clearly rejected, and where there is still some uncertainty in the law. ${ }^{10}$ According to the UNWCC, three defences commonly put forth together by the defendants in the post-World War II trials were the pleas of superior orders, duress, and military necessity. ${ }^{11}$ In addition to these three defences, other pleas of defence considered by the UNWCC included, inter alia: self-defence, legitimate reprisals, mistake of law and mistake of fact, and pleas relating to the mental capacity of the accused including limited mental capacity and drunkenness. All of these defences will be considered below.

Defences were also considered by the International Law Commission ('ILC') in its work on the Draft Code of Crimes against the Peace and Security

8 The Court may take some guidance from the Rules of Procedure and Evidence of the International Criminal Court, in particular Rules 79 and 80 which address issues procedure and of disclosure by the defence in relation to raising grounds excluding criminal responsibility. Rules of Procedure and Evidence, Official Records of the Assembly of States Parties to the Rome Statute of the International Criminal Court, (ICC-ASP/1/13 and Corr.1), First session, New York, 3-10 September 2002, part II.A. ('ICC Rules').

9 This report excludes the major trials conducted by the International Military Tribunal (Nuremberg Trial) and the International Military Tribunal for the Far East (Tokyo Trial) but does include the subsequent proceedings conducted in Nuremberg by the U.S. pursuant to Control Council Law No. 10 amongst other national war crimes trials. United Nations War Crimes Commission, Law Reports of Trials of War Criminals, Vol. XV - Digest of Laws and Cases (London: His Majesty's Stationery, 1949) at xvii ('UNWCC, Digest of Laws and Cases').

10 See, e.g., UNWCC, Digest of Laws and Cases, ibid., at 155-88.

${ }^{11}$ Ibid., at $155-6$. 
of Mankind. ${ }^{12}$ However, in its commentary on its 1991 draft Code, the Commission noted that in the opinion of some members, defences could never be invoked in connection with certain categories of crimes, such as crimes against humanity.' ${ }^{13}$ Rejecting that approach, Special Rapporteur Doudou Thiam proposed a new Article 14 which would recognize the defences of self-defence, coercion or state of necessity. ${ }^{14}$ In its final 1996 Draft Code of Crimes, the ILC returned to a generally worded Article 14, leaving it up to the competent international criminal jurisdiction to determine which defences are applicable 'in accordance with the general principles of law, in the light of the character of each crime'. ${ }^{15}$ Defences discussed by the ILC in its commentary on this broadly worded provision included: self-defence, superior orders, duress or coercion, military necessity, and mistake of fact. ${ }^{16}$

The ILC's work on the Draft Code of Crimes and the establishment of an international criminal jurisdiction was subsequently taken up by the Ad Hoc Committee on the Establishment of an International Criminal Court. In 1995, a Working Group of this Ad Hoc Committee prepared guidelines for consideration of questions of general rules of criminal law, including defences. ${ }^{17}$ The Ad Hoc Committee's Report included 'Guidelines for consideration of the question of general principles of criminal law' which contemplated a number of potential defences which should be considered upon further drafting.

${ }^{12}$ See, e.g., D. Thiam, Special Rapporteur, Fourth report on the Draft Code of Offences against the Peace and Security of Mankind, UN Doc. A/CN.4/398, 11 March 1986, in Yearbook of the International Law Commission 1986, Vol. II, Part One (New York: United Nations, 1988), UN Doc. A/CN.4/SER.A/1986/Add.1 (Part 1), at paras 185-254 ('Fourth report on the draft Code').

13 'Report of the Commission to the General Assembly on the Work of its Forty-Third Session,' in Yearbook of the International Law Commission 1991, vol. II, Part Two, UN Doc. A/CN.4/ SER.A/1991/Add.1 (Part 2), (UN: New York and Geneva, 1994) at 101.

${ }^{14}$ D. Thiam, Special Rapporteur, "Twelfth Report on the Draft Code of Crimes against the Peace and Security of Mankind' in Yearbook of the International Law Commission 1994, Volume II, Part One, UN Doc. A/CN.4/SER.A/1994/Add.1 (Part 1) (UN: New York and Geneva, 2001) 97 at 110 ('Twelfth report on the draft Code').

15 'Report of the International Law Commission on the work of its forty-eighth session (6 May 26 July 1996)', Document A/51/10 in Yearbook of the International Law Commission 1996, Volume II, Part II, UN Doc. A/CN.4/SER.A/1996/Add.1 (Part 2), (New York and Geneva: United Nations, 1998) at 39.

16 The ILC draft also considered a minimum age as a defence. The ILC discussed these defences, primarily with reference to the United Nations War Crimes Commission report. 'Report of the International Law Commission on the work of its forty-eighth session', ibid., at 40-41.

17 'Report of the Ad Hoc Committee on the Establishment of an International Criminal Court', General Assembly Official Records, 5oth sess., Supp. No. 22 (A/50/22) (1995) at 2 ('Report of the Ad Hoc Committee'). See also A. Eser, 'Article 31 - Grounds for excluding criminal responsibility' in Otto Triffterer (ed.), Commentary on the Rome Statute of the International Criminal Court, (2nd edn. Munich: C.H. Beck, 2008) 863, at 866. 
These Guidelines categorized defences into three groups: (a) Negation of liability, including: error of law, error of fact, diminished mental capacity to stand trial, and diminished mental capacity regarding liability; (b) Excuses and justifications, including: self-defence, defence of others, defence of property, necessity, lesser of evils, duress/coercion/force majeure, superior orders, and law enforcement/other authority to maintain order and (c) Defences under public international law/depending on jurisdiction, including: military necessity, reprisals, and Article 51 of the Charter of the United Nations. ${ }^{18}$

Some of the defences discussed in the course of drafting the statute of the ICC were ultimately included in Articles 31-33 of the Rome Statute of the International Criminal Court (Rome Statute). This is the first codification of defences for an international criminal tribunal or court. To date, these defences to liability constitute the most complete (though not exhaustive) statement of this aspect of general principles of law in an international instrument. With 123 states parties to the Rome Statute, many from Africa, these provisions provide a good starting point for the African Court, in particular because these provisions reflect some hard fought compromises in relation to some of the divergent approaches reflected amongst the different national legal systems. This Chapter will also look to the limited jurisprudence of the contemporary international criminal courts and tribunals on defences.

While historically some may have been hesitant to accept the application of defences to the most serious crimes, basic principles of criminal culpability are relevant to all criminal offences, including domestic crimes, international crimes, and transnational crimes. Despite the silence on the issue in the Malabo Protocol, defences cannot be ignored.

\section{SOURCES OF LAW}

Article 31 of the Malabo Protocol defines the applicable law before the African Court. Pursuant to this Article, the Court may turn to a wide range of relevant sources. General principles of law, referred to in Article $31(\mathrm{l})(\mathrm{d})$ of this instrument, is of particular importance in discerning applicable defences given the absence of codification on this issue in the Malabo Protocol. However, it is difficult to discern a general principle in relation to some questions relating to defences due to the different approaches taken in the various legal systems of the world. Accordingly, the question of how these lacunae are to be filled arises. Article 31(1)(f) permits the Court to turn to

18 'Report of the Ad Hoc Committee' ibid., Annex I, at 59-60. 
'[a]ny other law relevant to the determination of the case.' This arguably opens the door to consideration of domestic law.

The approach of resorting to national laws to fill lacunae in international law was contemplated by Judge Cassese at the ICTY. ${ }^{19}$ In drafting the statute for the International Criminal Court (ICC), there was debate surrounding the question of resorting to national law. ${ }^{20}$ Some expressed concern because resorting to national law would lead to 'inequality of treatment of accused' and 'inconsistent jurisprudence,' whereas others accepted the reality that there was not yet a complete body of international criminal law and accepted that national law could be relevant, but only as a last resort. ${ }^{21}$ As a practical matter,

19 ' $[\mathrm{A}]$ ssuming that no clear legal regulation of the matter were available in international law, arguably the Appeals Chamber majority should have drawn upon the law applicable in the former Yugoslavia.' Separate and Dissenting Opinion of Judge Cassese, Prosecutor v. Dražen Erdemović, (IT-96-22) Appeals Chamber, 7 October 1997, para. 49 ('Erdemović Appeal, Opinion of Judge Cassese').

$2 \circ$ 'Report of the Preparatory Committee on the Establishment of an International Criminal Court', Volume I (Proceedings of the Preparatory Committee during March-April and August 1996), General Assembly Official Records, 51st Sess., Supp. No. 22 (UN Doc. A/51/22), para. 187 ('1996 Report of the Preparatory Committee, Vol. I'). This approach was contemplated in the drafting history of the Rome Statute specifically with respect to defences. The draft statute forwarded by the Preparatory Committee to the Rome Conference included an Article 34, which left open the window for 'other grounds for excluding criminal responsibility':

Article 34(1) At trial the Court may consider a ground for excluding criminal responsibility not specifically enumerated in this part if the ground: (a) is recognized [in general principles of criminal law common to civilized nations] [in the State with the most significant contacts to the crime] with respect to the type of conduct charged; and (b) Deals with a principle clearly beyond the scope for excluding criminal responsibility enumerated in this part and is not otherwise inconsistent with those or any other provisions of the Statute.

'Report of the Preparatory Committee on the Establishment of an International Criminal Court', 14 April 1998, in United Nations Diplomatic Conference of Plenipotentiaries on the Establishment of an International Criminal Court, Official Records, Volume III, UN Doc. A/CONF.183/13 (Vol. III) (New York: United Nations, 2002) at 25 ('1998 Report of the Preparatory Committee').

${ }^{21} 1996$ Report of the Preparatory Committee, Vol I., ibid., para. 187. Article 21 as adopted in the Rome Statute includes as a final default source of law, 'general principles of law derived by the Courts from national laws of legal systems of the world including, as appropriate, the national laws of States that would normally exercise jurisdiction over the crime, provided that those principles are not inconsistent with this Statute and with international law and internationally recognized norms and standards.' Rome Statute of the International Criminal Court, A/CONF.183/9 of 17 July 1998, Art. 21(1)(c) ('Rome Statute'). This provision is a compromise achieved in Rome. M. M. deGuzman, 'Article 21 - applicable Law' in Otto Triffterer (ed.), Commentary on the Rome Statute of the International Criminal Court, (2nd edn., Munich: C.H. Beck, 2008) 701 at 702. 
the domestic law of a state which would otherwise have had jurisdiction may be a sensible source to turn to if no general principle can be discerned. This may also be justified as a question of fairness to the accused who would be expected to be aware of these laws.

\section{GROUNDS FOR EXCLUDING CRIMINAL RESPONSIBILITY}

IN ARTICLE 31 OF THE ROME STATUTE

In contrast to the silence seen in the statutes of the ad hoc international criminal tribunals, the Rome Statute is noteworthy for its codification of defences. It was felt at preliminary stages leading up to the adoption of the Rome Statute that the applicable law for the Court should include defences in order to increase the 'precision and certainty in criminal proceedings'. ${ }^{22}$ However, one commentator noted that Article 31 was one of the most difficult provisions on the general principles of criminal law to negotiate due to the many and sometimes fundamental differences on the law of defences among national legal systems. ${ }^{23}$

Therefore, in considering which defences the African Court may recognize, Article 31 of the Rome Statute is a helpful place to start. It includes in subsection (1) a non-exhaustive list of 'grounds for excluding criminal responsibility' (defences). Subsection (3) of the same Article explicitly re-affirms that this list of defences is non-exhaustive and the Court may recognize other defences in accordance with the relevant sources of law articulated in Article 21 including customary international law and general principles of law. This section of the chapter will consider the four defences explicitly enumerated in Article 31(1) of the Rome Statute, namely: mental disease or defect; intoxication; defence of person or property; and duress.

\section{A. Mental Disease or Defect}

The defence of mental disease or defect is explicitly included in the Rome Statute and has been recognized by the ICTY Appeals Chamber. Despite the fact that that this defence has been and is likely to remain rare in the case of international criminal tribunals, it's inclusion reflects the fact that it is a 'wellestablished principle of national criminal justice systems that incapacity or

${ }^{22}$ Report of the Ad Hoc Committee, supra note 17, at 10.

23 P. Saland, 'International Criminal Law Principles' in Roy S. Lee (ed.), The International Criminal Court: The Making of the Rome Statute Issues, Negotiations, Results (The Hague: Kluwer Law International, 1999) 189, at 206. 
legal insanity serves as a categorical exclusion of criminal responsibility. ${ }^{24}$ An individual who lacks the capacity to appreciate the wrongfulness of his or her conduct at the time when the crime was committed cannot be held criminally blameworthy for such conduct. This defence is a legally distinct question from the question of the accused's fitness to stand trial. Cassese points to the case of Stenger and Crusius before the Leipzig Supreme Court in 1921 as an historical example of a case in which such a defence was applied. ${ }^{25}$ Nonetheless, it has been noted that, generally, this defence did not get much attention in international criminal law until relatively recently. ${ }^{26}$

Given its general acceptance in national jurisdictions, it may have been anticipated that mental disease or defect would have been one of the least controversial defences leading up to Rome. However, there were still questions raised in the drafting of the Rome Statute about whether such a defence should be included and, if so, whether it should be applicable to all of the crimes within the Court's jurisdiction. ${ }^{27}$ Nonetheless, the defence of mental disease or defect was ultimately included in Article 31(1)(a) of the Rome Statute which states that an individual will not be criminally culpable for conducted committed when: "The person suffers from a mental disease or defect that destroys the person's capacity to appreciate the unlawfulness or nature of his or her conduct, or capacity to control his or her conduct to conform to the requirement of law'. This provision has been described as 'a fairly uncontroversial formulation of the defence. ${ }^{28}$ The defence articulated in the Rome Statute is made out if (a) the accused suffers from a mental disease or defect, and (b) that mental disease or defect either destroys the person's capacity to appreciate the unlawfulness or nature of his or her conduct or, alternatively, destroys the person's capacity to control his or her conduct to conform to the requirement of law. ${ }^{29}$ The threshold articulated in Article $31(1)(a)$ is high, requiring that

${ }^{24}$ Eser, supra note 18 , at 873 .

25 Cassese, International Criminal Law, supra note 1, at 263-4.

26 P. Krug, "The Emerging Mental Incapacity Defence in International Criminal Law: Some Initial Questions of Implementation', 94 American Journal of International Law (2000) 317, at 319 .

27 'Report of the Preparatory Committee on the Establishment of an International Criminal Court,' in Volume II, General Assembly Official Records, 51st sess., Supp. No. 22A, A/51/22 (New York: United Nations, 1996) at 97 ('1996 Report of the Preparatory Committee, Vol. II').

${ }_{28}$ Cryer et al., supra note 1 , at 401 .

29 This defence derives from the 'M'Naghten Rules' from common law. Knoops, supra note 1, at 109-10; W. A. Schabas, An Introduction to the International Criminal Court, (4th ed. Cambridge: Cambridge University Press, 2011) at 240. However, with respect to the language, 'mental disease or defect', Eser notes this formulation 'is directly taken from sec. 4.o1. U.S. 
the mental disease or defect destroys the person's capacity. ${ }^{30}$ This high threshold is understandable given that, if successfully established, it constitutes a complete defence from criminal responsibility for the most serious crimes. However, it has been suggested by Stanley Yeo that requiring destruction of capacity sets too high a threshold. ${ }^{31}$

The ICTY Appeals Chamber also recognized the existence of the defence of lack of mental capacity in the Čelebići case (although it was not applied to any accused in that case). ${ }^{32}$ According to the Appeals Chamber, an accused would be entitled to an acquittal if, "at the time of the offence [the accused] was labouring under such a defect of reason, from disease of the mind, as not to know the nature and quality of his act or, if he did know it, that he did not know that what he was doing was wrong. ${ }^{33}$ The ICTY Trial Chamber also recognized a presumption of sanity for all individuals charged with criminal acts. ${ }^{34}$ Accordingly, the ICTY Trial Chamber suggested that the onus lies on the accused to rebut this presumption on a balance of probabilities. ${ }^{35}$ This approach may make it harder for the accused to succeed on this defence but is not an unreasonable approach given the fact that, as the ICTY Trial Chamber points out, 'the facts $[. .$.$] are those peculiarly within [the accused's] know-$ ledge and should be established by him. ${ }^{36}$ It has been pointed out, however, that the ICC will likely take a different approach given the guarantee provided for in the Rome Statute that the accused has the right '[n]ot to have imposed on him or her any reversal of the burden of proof or any onus of rebuttal. ${ }^{37}$ Whether any onus of rebuttal may be placed on accused individuals before the African Court must be considered in relation to the Court's fair trial guarantees. The Malabo Protocol includes no explicit equivalent to this Rome Statute protection in its list of fair trial guarantees in Article $46 \mathrm{~A}$. However, the Court

Model Penal Code which supplements the cognitive focus of the (in)famous M'Naghten test with a volitional element.' Eser, supra note 18 , at 874 .

$3^{\circ}$ Cryer et al., supra note 1, at 401 ; Eser, supra note 18 , at 875 .

${ }^{31}$ '[T] $\mathrm{T}$ his word has the effect of unjustly denying the defence to persons who may have had the capacity to appreciate the nature or wrongness of their conduct or to control it but who, on the occasion in question, lacked such appreciation or control as a result of a mental disease or defect.' S. Yeo, 'The Insanity Defence in the Criminal Laws of the Commonwealth of Nations' 242 Singapore Journal of Legal Studies (2008) 241, at 259 ('The Insanity Defence').

${ }^{32}$ Judgment, Prosecutor v. Delalić et al. ('Čelebići case') (IT-96-21-A), Appeals Chamber, 20 February 2001, para. 582 ('Čelebići Appeal Judgment').

33 Ibid., at para. 582.

34 Judgment, Prosecutor v. Delalić et al. (IT-96-21-T), Trial Chamber, 16 November 1998, at para. 1157 ('Čelebići Trial Judgment').

35 Ibid., at para. 1158 \& 1160.

${ }^{6}$ Ibid., at para. 1158 .

37 Rome St., supra note 21, Art. 67(1)(i). See Krug, supra note 26, at 325. 
will have to determine how any potential substantive burden of proof on the defence is reconciled with the fundamental presumption of innocence included in Article 46A(3).

Another issue that the African Court will have to turn its head to is the question of what procedural rules will be required to facilitate this defence. For instance, given the need for psychiatric expertise in assessing this defence, the Court will need to determine the necessary rules of procedure and evidence including those relating to the admission of expert testimony and the availability and role of court appointed experts. ${ }^{3}$

Finally, the Court will also need to consider what happens if an accused successfully establishes this defence. Generally, rather than resulting in an outright acquittal, a successful assertion of a mental disorder defence results in a special disposition that the accused is 'not criminally responsible'. ${ }^{39}$ This raises the question of what recourse the Court has if an individual is found to have successfully made out the mental disorder defence but requires treatment or poses a threat to the safety of others. This question was raised in the process of drafting this provision of the Rome Statute but no clear rule was set out therein. This omission has been critiqued by commentators. ${ }^{40} \mathrm{~A}$ sensible solution posed by one commentator is that, in such a case, the ICC would enter into an agreement with a state party for the provision of medical services to such an individual. ${ }^{41}$ The African Court could take a similar course if the situation arose.

As noted above, the defence of mental disease or defect is a legally distinct question from the question of the accused's fitness to stand trial. Both questions relate to the accused's lack of capacity. However, fitness to stand trial is concerned with the accused's capacity at the start of and throughout a trial and says nothing about their criminal culpability, whereas the defence of mental disease and defect concerns the accused's criminal responsibility at the time of the commission of the offence. There are a number of examples throughout the history of trials for international crimes of individuals who have been found unfit to stand trial. ${ }^{42}$ Thus, the African Court must ensure that it adopts adequate rules and procedures ensuring that proceedings are stayed against

$3^{8}$ Krug, ibid., at 322-8.

39 Schabas, supra note 29, at 240.

$4 \circ$ Krug, supra note 26, at 333-4; Cryer et al., supra note 1, at 402.

$4^{11}$ Cryer et al., ibid.

$4^{2}$ In the trial of the major war criminals at Nuremberg by the International Military Tribunal, proceedings were postponed with respect to one of the accused, Gustav Krupp von Bohlen, because he was unfit to stand trial. International Military Tribunal, The United States of America et al. v. Göring et al, Order, in Trial of the Major War Criminals before the 
those who are lack the capacity to stand trial. The African Court may look to the ICC for guidance. The Rome Statute and the ICC's Rules of Procedure and Evidence require a Trial Chamber to satisfy itself that the accused understands the nature of the charges against him or her before it can proceed and requires that a Trial Chamber adjourn trial proceedings if an accused is found unfit to stand trial. ${ }^{43}$ The ICC's Rules of Procedure and Evidence allow for a medical, psychiatric or psychological examination of the accused to be ordered as necessary and provide for periodic review of any finding of unfit to stand trial. ${ }^{44}$

\section{Diminished Mental Capacity}

While mental disease or defect which amounts to lack of mental capacity has been accepted as a full defence in international criminal law, the defence of diminished mental capacity, recognized in some domestic jurisdictions, has been rejected. ${ }^{45}$ However, diminished mental capacity has been recognized as a factor which may be relevant to mitigation of sentence. ${ }^{46}$

Originating in the nineteenth century, the defence of diminished mental capacity was incorporated in the English Homicide Act 1957 as a partial defence to murder which, if established, would reduce the conviction to manslaughter. ${ }^{47}$ Such defence was available when the accused 'was suffering from such abnormality of mind (as defined) as substantially impaired his mental responsibility for his acts or omissions in doing so or being a party to the killing. ${ }^{38}$ This English statute provided a model for similar legislation in some other common law countries. ${ }^{49}$ The purpose of the defence was to prevent those who suffered from mental impairment, but who did not satisfy the high threshold of the full defence of mental disorder, from being

International Military Tribunal, vol. I, (published at Nuremberg, Germany, 1947) at 143. Ieng Thirith, one of the accused charged in Case 002 at the Extraordinary Chambers in the Courts of Cambodia ('ECCC'), was declared unfit to stand trial due to dementia. ECCC website: www.eccc.gov.kh/en/case/topic/2. At the ICTY, Dražen Erdemović was initially declared unable to stand trial due to serious post-traumatic stress disorder, however he was subsequently found fit to enter a guilty plea. Sentencing Judgment, Prosecutor v. Dražen Erdemović (IT-96-22-T), Trial Chamber, 29 November 1995, para. 5 ('Erdemović First Sentencing Judgment').

43 Rome St., supra note 21, Art. 64(8)(a); and ICC Rules, supra note 8, Rule 135(4).

44 See ICC Rules, supra note 8, at Rule 135.

45 Čelebići Appeal Judgment, supra note 32, at para. 839.

46 Ibid.

47 Ibid., at para. 585 .

$4^{8}$ Ibid.

49 Ibid, at para. 586. 
convicted of murder which was accompanied by harsh mandatory sentencing amounting at the time to 'either death or penal servitude for life. ${ }^{50}$

In the 'Celebići case' at the ICTY, one of the accused sought to raise the defence of diminished mental capacity. While the Tribunal's Statute is silent on the availability of such a defence, the accused pointed to a sub-Rule of the ICTY's Rules of Procedure and Evidence which refers to specific disclosure and notification obligations on an accused who seeks to raise 'any special defence, including that of diminished or lack of mental responsibility'. ${ }^{1}$ However, the Appeals Chamber of the ICTY concluded that new defences could not be adopted through the Rules. ${ }^{52}$ Accordingly, were such a defence to be applicable before the Tribunal, it must be found within the sources of international law. ${ }^{53}$ Finding no reference to such a defence in treaty or in customary international law, the Appeals Chamber turned to a consideration of general principles of law. ${ }^{54}$ The Appeals Chamber ultimately concluded that diminished mental responsibility is not a complete defence resulting in an acquittal. $^{55}$

The ICTY Appeals Chamber also rejected the appellant's submission that the Rome Statute of the ICC contemplated such a defence. ${ }^{56}$ The Appeals Chamber observed that, while the Rome Statute of the ICC includes a full defence when the accused's capacity is destroyed by a mental disease or defect, " $\mathrm{t}$ ]his is not the same as any partial defence of diminished mental responsibility, as it requires the destruction of (and not merely the impairment to) the defendant's capacity, and it leads to an acquittal. ${ }^{57}$

The Appeals Chamber of the ICTY did, however, conclude that there is a general principle of law that 'the defendant's diminished mental responsibility is relevant to the sentence to be imposed. ${ }^{5}$ This approach is also reflected in Rule 145(2)(a)(i) of the ICC's Rules of Procedure and Evidence

50 Ibid.

${ }^{1}$ Čelebići Trial Judgment, supra note 34, at para. 1156; Čelebići Appeal Judgment, supra note 32, at para. 582. At the time of the case, the Tribunal refers to sub-Rule 67(A)(ii)(b). However, this can now be found at Rule 67(B)(i)(b), ICTY, Rules of Procedure and Evidence, IT/32/Rev.50, 8 July 2015.

$5^{2}$ Čelebići Appeal Judgment, ibid., at para. 583.

53 Ibid.

54 Ibid.

55 Ibid, at para. 590.

${ }_{56}$ Ibid, at para. 584

57 Ibid, at para. 587 .

${ }_{5}^{8}$ Ibid, at para. 590. In the Čelebići case, the Trial Chamber rejected the application of diminished responsibility in relation to the accused in question. Čelebići Trial Judgment, supra note 34 , at para. 1186. 
which contemplates that 'circumstances falling short of constituting grounds for exclusion of criminal responsibility, such as substantially diminished mental capacity', may be taken into account as a mitigating factor in sentencing. ${ }^{59}$ Thus, diminished mental capacity has been recognized as a mitigating factor to be taken into account on sentencing but has been rejected as a complete defence in international criminal law. A similar approach which would have explicitly recognized diminished mental capacity as mitigation on sentencing was considered in the drafting history leading up to the Rome Statute but was not, ultimately, included. ${ }^{60}$ However, at the same time, Article 76 of the Rome Statute on sentencing leaves a large amount of discretion to the Trial Chamber to determine the appropriate sentence which would, of course, include consideration of any relevant aggravating or mitigating factors. The Malabo Protocol contains similarly broad language, specifying that: 'In imposing the sentences and/or penalties, the Court should take into account such factors as the gravity of the offence and the individual circumstances of the convicted person. ${ }^{61}$

The ICTY Appeals Chamber's reasoning for rejecting the defence of diminished mental capacity is persuasive. In particular, the Appeals Chamber noted that the rationale earlier referenced for the recognition of such a defence in English law did not apply to the Tribunal, in particular because there is no mandatory sentencing and because there is no 'appropriate lesser offence available under the Tribunal's Statute for which the sentence would be lower and which could be substituted for any of the offences it has to try. ${ }^{62}$ Accordingly, the African Court should follow the approach articulated by of the ICTY and consider the general principle that diminished mental capacity of an accused that does not amount to the defence of mental disease or defect is relevant to sentencing as a potential mitigating factor.

\section{B. Intoxication}

The availability of the defence of intoxication in international law is a more controversial issue. Intoxication is a challenging defence even in those domestic jurisdictions which do recognize it in some form. The perceived

59 ICC Rules, supra note 8, at Rule $145(2)(a)(i)$. See also Eser, supra note 18, at 875 .

6o Preparatory Committee on the Establishment of an International Criminal Court, Working Group on General Principles of Criminal Law and Penalties, 'Working Paper Submitted by Argentina, Canada, France, Germany, Mexico, Portugal and the United States of America', 21 February 1997, A/AC.249/1997/WG.2/DP.3, footnote 3.

61 Art. $43 \mathrm{~A}(4)$.

62 Čelebići Trial Judgment, supra note 34, at para. 590. 
culpability in voluntarily becoming intoxicated and then committing a serious crime, combined with the concern that intoxication is too often present in the commission of many serious offences like sexual assault, suggests that the defence of intoxication should be limited. A similar concern has been raised in relation to the prevalence of intoxication and the commission of international crimes including in Rwanda where it has been suggested that ' $[\mathrm{m}]$ any of the participants in Rwanda's genocide were drunk'. ${ }^{63}$ On the international level, this debate is further complicated because some countries not only reject intoxication as a defence but treat it as an aggravating factor in the commission of a crime. ${ }^{64}$

Early discussion of defences in the drafting history of the ICC indicate that there was support for the view that the intoxication defence was not relevant to the types of crimes within the jurisdiction of the Court. ${ }^{65}$ "There was no great substantive disagreement on permitting involuntary intoxication as a ground for excluding criminal responsibility. But voluntary intoxication presented big problems. ${ }^{66}$ Thus, some proposals would have excluded this defence in all cases of voluntary intoxication, whereas other proposals suggested that the defence of intoxication be recognized but only when the person is 'unable to formulate the mental element of the crime. ${ }^{67}$ Schabas has echoed this concern and suggested that voluntary intoxication is 'virtually inconsistent' with the nature of the crimes within the jurisdiction of the ICC, in particular in light of the fact that the Court was designed to prosecute 'a relatively small number of leaders, organizers and planners' ${ }^{68}$ The same argument could potentially be made with respect to the Malabo Protocol although there is a much broader range of crimes within the jurisdiction of this instrument and there is no explicit indication the African Court would only prosecute senior leaders who planned and organized crimes. Furthermore, despite these concerns, a very limited form of intoxication defence was in the end included in the Rome Statute.

63 Cryer et al., supra note 1 , at 402 .

64 Eser, supra note 18 , at 877 .

${ }_{5}$ The Preparatory Committee on the Establishment of an International Criminal Court noted that it was ... generally felt that only defences relevant to the types of crimes under the statute would be included. Accordingly, it was suggested, for example, that intoxication and insanity did not have to be included in the statute.' 1996 Report of the Preparatory Committee, Vol. I, supra note 20, at para. 204. See also Eser, supra note 18 , at 876 .

66 Saland, supra note 23 , at 207.

671996 Report of the Preparatory Committee, Vol. II, supra note 27, at 98.

68 Schabas, supra note 29, at 240-1. 
The important distinction between voluntary and involuntary intoxication has also been noted by the ICTY. In one ICTY case, an accused attempted to raise intoxication as a mitigating factor in sentencing. ${ }^{69}$ The Trial Chamber rejected the argument, observing that " $[w]$ hile a state of intoxication could constitute a mitigating circumstance if forced or coerced, the Trial Chamber cannot accept [the] contention that an intentionally procured diminished mental state could result in a mitigated sentence. ${ }^{70}$ The Trial Chamber suggested instead that voluntary intoxication was an aggravating factor, "particularly in contexts where violence is the norm and weapons are carried'. ${ }^{71}$ The Appeals Chamber affirmed that intoxication was not a mitigating factor when the accused becomes voluntarily intoxicated. ${ }^{72}$

Despite the challenges involved in drafting, a limited intoxication defence was included in the Rome Statute. Article 31(1)(b) of the Rome Statute holds that a person will not be criminally responsible if, at the time:

The person is in a state of intoxication that destroys that person's capacity to appreciate the unlawfulness or nature of his or her conduct, or capacity to control his or her conduct to conform to the requirements of law, unless the person has become voluntarily intoxicated under such circumstances that the person knew, or disregarded the risk, that, as a result of the intoxication, he or she was likely to engage in conduct constituting a crime within the jurisdiction of the Court;

As noted by Per Saland, chair of the working group on the general principles of criminal law at Rome, the provision adopted 'tries to position itself in the middle by making the exception as broad as possible without totally excluding voluntary intoxication as a ground for excluding criminal responsibility'. ${ }^{73}$

It is evident from the language of Article 31(1)(b) that it contemplates only a restrictive intoxication defence. The defence, as set out in the Rome Statute, applies only if the intoxication 'destroys that person's capacity'. Accordingly, it is not sufficient to demonstrate that an accused's capacity is simply impaired. ${ }^{74}$

69 Judgment, Prosecutor v. Kvočka et al. (IT-98-30/1-T), Trial Chamber, 2 November 2001, para. 691 ('Kvočka Trial Judgment'). See Cassese, International Criminal Law, supra note 1, at 266-7.

70 Kvočka Trial Judgment, ibid, at para. 706. [Emphasis added]

${ }^{71}$ Ibid. However, Žigićs's intoxication was not applied as an aggravating factor in that case because it was not raised by the Prosecutor.

72 Judgment, Prosecutor v. Kvočka et al. (IT-98-30/1-A), Appeals Chamber, 28 February 2005, para. 707, with reference to two other prior ICTY Sentencing Judgments, thus concluding that ' $[\mathrm{t}]$ he jurisprudence of this Tribunal is clear' on that issue.

73 Saland, supra note 23, at 207. See also Eser, supra note 18, at 876-7.

74 See Cryer et al., supra note 1 , at 403 . 
This is an extremely high threshold and will exclude the vast majority of individuals who commit crimes while intoxicated. Furthermore, the defence is circumscribed in situations of voluntary intoxication by excluding situations in which the person voluntarily becomes intoxicated "under such circumstances that the person knew, or disregarded the risk, that, as a result of the intoxication, he or she was likely to engage in conduct constituting a crime within the jurisdiction of the Court'. Thus, the fault of intentionally becoming intoxicated in such situations precludes the availability of the defence of intoxication. This has been described as 'a recklessness test'. ${ }^{75}$

Given the contradictory approach taken with respect to the impact of intoxication on an accused's criminal responsibility among the legal systems of the world, there is 'really no way of reconciling these differences' ${ }^{7}$ Furthermore, intoxication is a controversial defence even in those jurisdictions in which it is recognized. The justification for permitting such a defence is, generally, that it is unjust to hold an individual criminally responsible if they lack mens rea. ${ }^{77} \mathrm{~A}$ high threshold should be required in relation to any defence of intoxication permitted before the African Court in light of the serious nature of all of the crimes contained within the jurisdiction of the Court, particular in relation to voluntary intoxication. Thus, the approach taken in the Rome Statute, while described by Saland as not fully satisfying anyone, may provide guidance to the Court on this issue. ${ }^{7^{8}}$

\section{Defence of Person or Property}

Defence of the person, including self-defence and defence of others, is one of the most universally accepted criminal defences. ${ }^{79}$ Defence of property, particularly in relation to an allegation of serious international or transnational crimes, is more controversial. ${ }^{80}$ The question of whether defence of property should be included in the ICC's statute as a ground for excluding criminal responsibility proved to be one of the most difficult issues in negotiations on

75 Ibid.

76 Saland, supra note 23, at 207.

77 See, e.g., Knoops, supra note 1, at 116.

$7^{8}$ Ibid.

79 Self-defence has been described as 'a paradigmatic justification of conduct.' Cryer et al., supra note 1 , at 404 .

8० As Yeo observes, 'legal convention accords a higher value to the human body or bodily integrity than to property.' Stanley Yeo, 'Anglo-African Perspectives on Self-Defence' 17 African Journal of International Law and Comparative Law (2009) 118, at 119. 
this subject. ${ }^{81}$ The provision finally agreed to is included in Article $31(1)(\mathrm{c})$ of the Rome Statute. This provision states that an accused will not be criminally responsible if, at the relevant time:

The person acts reasonably to defend himself or herself or another person or, in the case of war crimes, property which is essential for the survival of the person or another person or property which is essential for accomplishing a military mission, against an imminent and unlawful use of force in a manner proportionate to the degree of danger to the person or the other person or protected property. The fact that the person was involved in a defensive operation conducted by forces shall not in itself constitute a ground for excluding criminal responsibility under this subparagraph;

Thus, the Rome Statute includes the defence of the person (both self-defence and defence of others) and, in more limited terms, defence of property.

It is important to clarify that, of course, self-defence here refers to the defence of the person, which is a legally distinct issue from self-defence of the state under Article 51 of the UN Charter. The fact that an individual is acting as a part of an operation which constitutes a part of a state's actions in self-defence is not in itself a defence to the perpetration of international crimes. Furthermore, as explicitly stated in Article $31(1)(\mathrm{c})$ of the Rome Statute, " $\mathrm{t}$ ] he fact that the person was involved in a defensive operation conducted by forces' is not a ground excluding criminal responsibility in international law. Thus, for the purposes of this section, self-defence refers only to individual defence of the person.

\section{Defence of the Person}

Self-defence or the defence of others is a generally accepted ground for excluding criminal responsibility. For example, in its commentary on its final draft Code of Crimes, the ILC recognized the 'classic defence' of selfdefence. ${ }^{82}$ Cassese notes that Article 31(1)(c) of the Rome Statute, at least as it applies to defence of persons, reflects customary international law. ${ }^{83}$ In addition to its codification in the Rome Statute, self-defence has been recognized as an accepted defence by the UNWCC, the ILC and the ICTY.

The UNWCC recognized that the defence of self-defence was applicable to war crimes and pointed to one trial before a United States Military Court

${ }^{81}$ Saland, supra note 23, at 207 .

82 'Report of the International Law Commission on the work of its forty-eighth session', supra note 15 , at 40 .

$8_{3}$ Cassese, International Criminal Law, supra note 1, at 261. 
where the plea of self-defence was successful. ${ }^{84}$ The ILC similarly observed that self-defence "could relieve an accused of criminal responsibility for the use of force against another human being resulting in death or serious injury if this force was necessary to avoid an immediate threat of his own death or serious injury caused by that other human being' ${ }^{85}$ The ILC pointed in particular to the Convention on the Safety of United Nations and Associated Personnel as an example of the implicit recognition of self-defence in international law. 86

One ICTY Trial Chamber recognized self-defence as a rule of customary international law. ${ }^{87}$ It defined self-defence as 'providing a defence to a person who acts to defend or protect himself or his property (or another person or person's property) against attack, provided that the acts constitute a reasonable, necessary and proportionate reaction to the attack. ${ }^{, 88}$

With reference to the text of Article 31(1)(c) of the Rome Statute and the definition suggested by the ICTY, the parameters of self-defence must be considered. First, to which threats can a person legitimate respond in selfdefence? Secondly, what conditions govern the accused's response to that threat? ${ }^{89}$ Finally, does the accused's prior fault preclude them from relying on self-defence?

What parameters govern the threat which gives rise to the right of an individual to act in self-defence? Not much guidance can be derived on this issue from the broad definition of self-defence put forth by the ICTY which simply says that a person may act 'to defend or protect himself or his property (or another person or person's property) against attack'. On the other hand, Article $31(1)(c)$ of the Rome Statute gives us more guidance, requiring that an

84 UNWCC, Digest of Laws and Cases, supra note 9, at 177. See also 'Report of the International Law Commission on the work of its forty-eighth session', supra note 15, at 40; Cassese, ibid., at 260 .

85 'Report of the International Law Commission on the work of its forty-eighth session', ibid., at 40 .

86 Ibid. See Convention on the Safety of United Nations and Associated Personnel, 9 December 1994, 2051 UNTS 363, Art. 21.

87 Kordić and Čerkez Trial Judgment, supra note 6, at paras $449 \& 451$. See Cryer et al., supra note 1 , at 404 .

88 Kordić and Čerkez Trial Judgment, ibid., at paras $449 \& 451$.

${ }^{89}$ Yeo segregates his analysis on self-defence to consider these two over-arching questions which provides a useful way of analysing the parameters of the law. Yeo, 'Anglo-African Perspectives on Self-Defence', supra note 8o. Yeo's work in this paper compares the Rome Statute provision in self-defence to the criminal law in five African countries which are former British colonies, including: Botswana, Ghana, Nigeria (the Southern Nigerian Criminal Code), Sudan and Kenya 
accused be acting in response to an 'imminent and unlawful use of force. $9{ }^{\circ}$ This seems to track the attitude towards this defence in many domestic jurisdictions.

Another question that arises is whether the law is only concerned with the accused's perception of the threat or whether that threat must be 'objectively demonstrable' (or some combination of a subjective and objective assessment). Yeo suggests that, "[o]n a strict reading of Article $3^{1}(1)$ (c) of the ICC Statute, the threat must have been real, that is, it must have existed as an objectively demonstrable fact. ${ }^{\prime 11}$ However, failing to find this approach in any of the other domestic laws that he studied, Yeo suggests that the best approach is to adopt a hybrid subjective/objective test based on the 'accused's reasonable belief. ${ }^{9^{2}}$ Yeo suggests further that personal characteristics of the individual, such as their 'age, sex, physical disabilities, religious beliefs, ethnicity, vulnerability (but excluding psychiatric conditions)' should be considered when applying this test. ${ }^{93}$

Second, what is required with respect to the accused's response to such an 'imminent and unlawful use of force' in order for self-defence to be available? Pursuant to Article $31(1)(\mathrm{c})$ of the Rome Statute, the individual must act 'reasonably' and 'in a manner proportionate to the degree of danger'. ${ }^{94} \mathrm{On}$ the other hand, the ICTY states that the individual's acts must be 'reasonable, necessary, and proportionate.' While it may be beneficial to articulate a requirement that the act be necessary as distinct from the requirement of reasonableness, 'a response which was unnecessary would also be unreasonable.' 95 Cassese refers to the requirement of self-defence that 'there is no other way of preventing or stopping the offence. ${ }^{96}$ This raises the question of whether one must retreat before acting in self-defence. ${ }^{97}$ One British Military Court

90 Eser notes that, "there is common agreement that a use of force is imminent if it is immediately antecedent, presently exercised or still enduring. Thus, a defender neither has to wait until a danger has become present, nor is it allowed to use pre-emptive or even preventive means to circumvent a use of force, nor is it permitted to retaliate against an already passed attack.' Eser, supra note 18 , at 880-1.

91 Yeo, supra note 80 , at 123.

$9^{2}$ Ibid., at 125 .

93 Ibid.

94 Yeo characterizes the Rome Statute provision as requiring the reasonableness and proportionality of the accused's acts to be assessed on a 'robustly objective test' but suggests again that a hybrid test is to be preferred. Such a test takes account relevant individual characteristics of the accused, which focuses on 'the accused's belief based on reasonable ground, that the response was necessary, reasonable and proportionate'. Ibid., at 132-3.

95 Ibid., at 127.

96 Cassese, International Criminal Law, supra note 1, at 259.

97 Yeo, 'Anglo-African Perspectives on Self-Defence', supra note 80, at 129-30. 
said in a post-World War II war crimes trial that: 'The law permits a man to save his own life by dispatching that of another, but it must be in the last resort. $\mathrm{He}$ is expected to retreat to the uttermost before turning and killing his assailant. ${ }^{98}$ Whereas English common law traditionally obliged individuals to retreat, the law has evolved such that 'the opportunity to retreat is simply a factor to be taken into account when deciding the general question as to whether the accused's response was reasonably necessary.'99 Furthermore, debates in domestic law about whether an individual bears a duty to retreat before using force become more complicated in the context of war crimes trials where the very nature of the conflict involves the causing of death of opposing forces. Thus, a more flexible rule emphasizing the reasonableness and proportionality of the act are better suited to take into consideration all of the circumstances of the case.

One final question is whether the accused is precluded from relying on selfdefence if some prior fault for the situation lies upon them, for example, 'where the accused had assaulted or provoked an assault from another'. ${ }^{100}$ Cassese suggests that an individual can only rely on self-defence if "the unlawful conduct of the other has not been caused by the person acting in self-defence. ${ }^{101}$ The text of the draft statute forwarded by the Preparatory Committee to the Rome Conference included a bracketed phrase which would limit the applicability of self-defence such that a person would only be entitled to such a defence provided that he or she did not put himself or herself voluntarily into a position causing the situation to which that ground for excluding criminal responsibility would apply' ${ }^{102}$ However, this language does not ultimately appear in the final version of Article 31(1)(c) of the Rome Statute. A review of relevant domestic jurisdictions would be prudent to determine whether a general principle of law can be discerned with respect to this potential exclusionary rule.

\section{Defence of Property}

Whereas Article 31(1)(c)'s codification of defence of person may reflect customary international law, the defence of property is more controversial.

$9^{8}$ UNWCC, Digest of Laws and Cases, supra note 9, at 177.

99 Yeo, 'Anglo-African Perspectives on Self-Defence', supra note 80, at 129. See also Andrew J. Ashworth, 'United Kingdom' in Kevin Jon Heller and Markus D. Dubber (eds), The Handbook of Comparative Criminal Law (Stanford: Stanford University Press, 2011) 531, at 542.

${ }^{100}$ Stanley Yeo, 'Anglo-African Perspectives on Self-Defence', supra note 80, at 130.

${ }_{101}$ Cassese, International Criminal Law, supra note 1, at 259.

1021998 Report of the Preparatory Committee, Vol. III, supra note 20, at 34. 
As stated above, this proved to be one of the most difficult issues to resolve in the negotiations on defences in Rome and was described as the real cliffhanger' for the working group that was drafting the provision. ${ }^{103}$

The approach taken in Article 31(1)(c) limits defence of property to two situations. First, acts may be taken in defence in relation to "property which is essential for the survival of the person or another person'. The inclusion of this category of property seems more justifiable given that a threat to property essential to the survival of persons indirectly amounts to a threat to those persons. ${ }^{104}$ Thus, it has been described as 'merely a special case of the general and uncontroversial protection of a person's life. ${ }^{105}$ However, the second category is far more controversial. It permits acts to be taken in defence of 'property which is essential for accomplishing a military mission.'

The defence of property is limited in Article 31(1)(c) of the Rome Statute solely to the category of war crimes. It is therefore not permitted in relation to charges of genocide, crimes against humanity, or aggression. This was added despite the fact that the starting point was that the general principles of criminal law would be generally applicable to all crimes within the jurisdiction of the Court. ${ }^{106}$ While war crimes are also treated differently in relation to the availability of the defence of superior orders in the Rome Statute (as discussed above), this restriction in relation to defence of property is the only situation in which any of the Article 31 grounds for excluding responsibility is excluded from some of the crimes within the court's jurisdiction.

Including defence of property in Article 31 of the Rome Statute has been highly criticized for its departure from the position of customary international law. ${ }^{107}$ Thus, the African Court may choose not to follow this approach. If defence of property is permitted, it should be more circumscribed than defence of persons in light of the serious nature of the crimes included in the subject matter jurisdiction of the Court. Furthermore, it is necessary to recall that all acts in defence of essential property must be both reasonable and proportionate. ${ }^{108}$

${ }^{103}$ Saland, supra note 23, at 208.

104 Ibid.

${ }^{105}$ Eser, supra note 18 , at 881 .

${ }^{106}$ Saland, supra note 23, at 208.

${ }^{107}$ Cassese, International Criminal Law, supra note 1, at 261. See also Antonio Cassese, "The Statute of the International Criminal Court', supra note 37, 144 at 154-5; Eser, supra note 18, at 881 .

${ }^{108}$ Rome Statute, supra note 21, at Art. 31(1)(c). There may also be civil (tort law) implications of this defence, however, this lies beyond the scope of this chapter. 


\section{Duress and Necessity}

\section{Duress}

One defence which has received judicial consideration in the existing war crimes jurisprudence is the defence of duress. However, the jurisprudence does little to resolve some of the most challenging questions about the limits of the law of duress. Can duress be raised as a defence to a charge of murder? Does the nature of genocide or crimes against humanity alter our assessment of the applicability of the defence of duress? What if the individual faces the choice of killing civilians or being killed alongside them? The tension in the international criminal jurisprudence derives from the diverging approaches taken by national jurisdictions on these questions. This makes it difficult to discern a clear general principle on the law of duress. ${ }^{109}$ Additionally, there is still tension within some national jurisdictions as courts grapple with some of these most difficult questions about law and morality and proportionality analyses involving human lives.

Throughout the history of international criminal law, duress has also been referred to as necessity, extreme necessity, compulsion, force and compulsion, coercion, and coercion and compulsory duress. ${ }^{110}$ As defined by the

109 The post-World War II decisions, which are relied upon in the more recent jurisprudence for guidance, relied themselves on these divergent national rules. See, e.g., , Joint Separate Opinion of Judge McDonald and Judge Vohrah, Prosecutor v. Dražen Erdemović (IT-96-22) Appeals Chamber, 7 October 1997, para. 54 ('Erdemović Appeal, Opinion of Judge McDonald and Judge Vohrah').

${ }^{110}$ See, e.g., UNWCC, Digest of Laws and Cases, supra note 9 at 170; 'Report of the International Law Commission on the work of its thirty-eighth session (5 May-11 July 1986),' Document A/41/ 10 in Yearbook of the International Law Commission 1986, Volume II, Part II (United Nations: New York, 1987), UN Doc. A/CN.4/SER.A/1986/Add.1 (Part 2) at 51; Sentencing Judgment, Prosecutor v. Dražen Erdemović (IT-96-22-T), Trial Chamber, 26 November 1996, para. 16; Opinion of Judge Cassese, Erdemović Appeal, supra note 19, at para. 14. Reports of the International Law Commission on the Draft Code of Offences against the Peace and Security of Mankind also refer to the defence of force majeure, however, it notes that 'the concept [of force majeure], at least in certain legal systems is more closely related to the general theory of civil liability and, if it arises in criminal law, it does so in connection with unintentional offences such as homicide by negligence, resulting from example from a traffic accident.' Thiam, 'Fourth report on the draft Code', supra note 12, at para. 201. Cassese comments that '[i]t is doubtful whether force majeure is admissible (the existence of an irresistible force or an unforeseen external event beyond the control of a belligerent which makes it absolutely and materially impossible for the belligerent to comply with a rule of humanitarian law: for instance, non-compliance with some rules on the treatment of prisoners of war on account of an earthquake, or, of a famine not caused by the belligerent); this excuse, if admissible, should, however, be strictly construed to avoid abuse by combatants.' Cassese, International Criminal Law, supra note 1 , at $25^{8}$. 
UNWCC, the plea of duress amounts to " $t$ ] he argument that, in committing the acts complained of, the accused acted under an immediate threat to himself. ${ }^{111}$ In the words of ILC Special Rapporteur on the Draft Code of Offences against the Peace and Security of Mankind, Doudou Thiam: 'Coercion involves the threat of an imminent peril from which it is impossible to escape except by committing the offence. ${ }^{112}$ In this chapter, duress and necessity will be distinguished. The term duress will be used to refer to cases in which such threat emanates from another person or persons and necessity will be used in relation to situations in which such threat results from 'objective circumstances'. ${ }^{113}$

Historically, the question of duress was often bound up in law and in fact with the defence of superior orders. ${ }^{114}$ In the International Military Tribunal's discussion of the exclusion of the defence of superior orders in Article 8 of the Nuremberg Charter, it noted: "The true test, which is found in varying degrees in the criminal law of most nations, is not the existence of the order, but whether moral choice was in fact possible. ${ }^{\prime 15}$ This approach which links superior orders and duress was followed in Principle IV of the Nürnberg Principles and in the ILC's first draft code of offences against peace and security in $1954 .{ }^{116}$ However, it is clear that the questions of superior orders

${ }^{111}$ UNWCC, Digest of Laws and Cases, supra note 9, at 156.

${ }_{112}$ Thiam, 'Fourth report on the draft Code', supra note 12, at para. 191.

${ }^{113}$ See Cassese, International Criminal Law, supra note , 1 at 280.

${ }^{114}$ Erdemović Appeal, Opinion of Judge Cassese, supra note 19, at para. 15: 'in the case-law, duress is commonly raised in conjunction with superior orders. However, there is no necessary connection between the two.' The ICTY Trial Chamber in the Erdemović case appears to have conflated the two issues to some degree when it seemed to suggest that proof of the existence of a superior order was a requirement to establish the defence of duress. Erdemović First Sentencing Judgment, supra note 42 , at para. 19. However, this was overruled by the Appeals Chamber. Erdemović Appeal, Opinion of Judge McDonald and Judge Vohrah, supra note 109, para. 35 .

${ }^{115}$ Trial of the Major War Criminals before the International Military Tribunal, Göring et al., Judgment (Nuremberg, 1947), at 224. (Emphasis added) As described in one book, 'one of the most plausible explanations of the way in which the Nuremberg IMT dealt with its provision on superior orders is that it laid down a test for duress.' Cryer et al., supra note 1, at 407 .

${ }^{116}$ Thiam, 'Fourth report on the draft Code', supra note 12, at paras 218-26. Principle IV of the Principles of International Law Recognized by the Charter of the Nürnberg Tribunal and in the Judgment of the Tribunal states that: "The fact that a person acted pursuant to an order of his Government or of a superior does not relieve him from responsibility under international law, provided a moral choice was in fact possible to him.' (emphasis added) Yearbook of the International Law Commission 1950, Volume II (New York: United Nations, 1957), UN Doc. A/CN.4/SER.A/1950/add.1, at 375. A variation on this appears in the ILC's 1954 draft code of offences against the peace and security of mankind which reads: "The fact that a person charged with an offence defined in this Code acted pursuant to an order of his Government or of a superior does not relieve him of responsibility in international law if, in the circumstances 
and the defence of duress must be analysed separately. ${ }^{117}$ While they may arise factually in the same circumstances, these are two distinct legal questions which must be conceptually separated and analysed individually. ${ }^{118}$

The UNWCC considered the plea of duress in its summary of the postWorld War II War Crimes Trials. It recognized that duress had been accepted in certain cases as a complete defence. ${ }^{119}$ For example, duress was recognized in the three cases under Control Council Law No. 10 involving the prosecution of German industrialists charged with using forced labour. ${ }^{120}$ As summarized by the Commission: 'In the Flick, I.G. Farben and Krupp Trials, the plea put forward was that the accused were obliged to meet the industrial production quotas laid down by the German Government and that in order to do so it was necessary to use forced labour supplied by the State, because no other labour was available, and that had they refused to do so they would have suffered dire consequences. ${ }^{121}$ The defence was in fact successful for many of the accused in the Flick case. ${ }^{122}$

The UNWCC also referred to a handful of other post-World War II cases which appeared more hesitant to allow the defence of duress, in particular in relation to cases involving allegations of killing innocent persons. For example, in Fuerstein et al., a British Military Court stated: 'You are not entitled, even if you wished to save your own life, to take the life of another. ${ }^{\text {'123 }}$ In Hölzer et al., the Judge Advocate of a Canadian Military Court stated: 'There is no doubt on the authorities that compulsion is a defence when the crime is not of a heinous character. But the killing of an innocent person cannot be justified. ${ }^{124}$ On the other hand, the United States Military Tribunal acting under Control Council Law No. 10 in the Einsatzgruppen Trial

at the time, it was possible for him not to comply with that order.' (emphasis added) Draft Code of Offences against the Peace and Security of Mankind 1954 (United Nations, 2005), available online at: legal.un.org/ilc.texts/instruments/English/draft_articles/7_3_1954.pdf. See also Bantekas, supra note 1 , at 106.

${ }^{117}$ See also Cassese, International Criminal Law, supra note 1, at 284-5.

${ }^{118}$ See also Erdemović Appeal, Opinion of Judge McDonald and Judge Vohrah, supra note 109, at para. 35 .

119 UNWCC, Digest of Laws and Cases, supra note 9, at 156.

${ }^{120}$ See, e.g., Separate and Dissenting Opinion of Judge Li, Prosecutor v. Dražen Erdemović (IT96-22), Appeals Chamber, 7 October 1997, at para. 6 ('Erdemović Appeal, Opinion of Judge

Li'). These cases refer to 'necessity' but appear to apply the defence of duress (excusing unlawful conduct which was compelled by 'dire consequences'). See also J. D. Ohlin, 'The Bounds of Necessity' 6 Journal of International Criminal Justice (2008) 289 at 293-4.

${ }^{121}$ UNWCC, Digest of Laws and Cases, supra note 9, at 171.

${ }^{122}$ Ibid., at 172 .

123 Ibid., at 173 .

${ }^{124}$ Ibid. 
expressed the contrary view: 'Let it be said at once that there is no law which requires that an innocent man must forfeit his life or suffer serious harm in order to avoid committing a crime which he condemns. The threat, however, must be imminent, real and inevitable. No court will punish a man who, with a loaded pistol at his head, is compelled to pull a lethal lever. Nor need the peril be that imminent in order to escape punishment. ${ }^{125}$ Thus, while duress was recognized as a complete defence (and not merely as a mitigation of sentence) in the German industrialist cases in relation to charges of forced labour, we are left with an unclear picture about whether duress can be invoked as a complete defence in cases of war crimes or crimes against humanity involving the taking of lives.

Despite the limited jurisprudence from the ad hoc Tribunals on defences, duress was considered extensively by the ICTY in the case of Prosecutor v. Dražen Erdemović. However, as a result of the silence in the Tribunal's Statute on defences, the diverging perspectives on duress in national law, and the lack of consensus in the post-World War II war crimes jurisprudence, the judges of the ICTY also diverged in their views and in their reasoning with respect to the applicability of the defence of duress. A bare majority of the ICTY Appeals Chamber concluded that duress is not a complete defence in relation to charges of war crimes and crimes against humanity involving killing innocent persons and can only be a mitigating factor in such cases. ${ }^{126}$ However, it has been observed that 'the existing doctrine is still far from being solidified, given that the Erdemović case was decided by a mere $3^{-2}$ vote and the dissenting opinion of Judge Cassese has had as much influence as the majority opinion. ${ }^{, 27}$

The accused in that case, Dražen Erdemović, was a 23-year-old member of the Bosnian Serb army who, with other members of his unit, formed part of a firing squad that killed approximately 1200 unarmed civilian men after of the fall of Srebrenica. ${ }^{128}$ Erdemović estimated that he himself probably

125 Ibid., at 174 . However, the statements in the Fuerstein and in the Einsatzgruppen cases have both been characterized as mere obiter dictum. See Erdemović Appeal, Opinion of Judge Cassese, supra note 19, at para. 25; Erdemović Appeal, Opinion of Judge Li, supra note 120, at para. 10.

${ }^{126}$ Erdemović Appeal, Opinion of Judge McDonald and Judge Vohrah, supra note 109, at para. 88. This conclusion as supported by Judge Li in his Separate and Dissenting Opinion, Erdemović Appeal, Decision of Judge Li, ibid., at para. 12.

${ }^{127}$ Ohlin, supra note 120 , at 291.

${ }^{128}$ Erdemović First Sentencing Judgment, supra note 42, at paras 2-3, 76-8 \& 95; Judgment, Prosecutor v. Dražen Erdemović (IT-96-22-A), Appeals Chamber, 7 October 1997, at para. 1 ('Erdemović Appeal Judgment'). 
killed around seventy people. ${ }^{129}$ In his submission of his guilty plea, Erdemović stated:

Your Honour, I had to do this. If I had refused, I would have been killed together with the victims. When I refused, they told me: 'If you're sorry for them, stand up, line up with them and we will kill you too.' I am not sorry for myself but for my wife and son who then had nine months, and I could not refuse because then they would have killed me'. ${ }^{130}$

The Trial Chamber, accordingly, considered the defence of duress but concluded that it could not exonerate the accused. ${ }^{131}$ The Trial Chamber's reasoning, in part, suggested that duress could not be raised in relation to crimes against humanity due to the fact that such an act could not satisfy the proportionality requirement because 'the life of the accused and that of the victim are not fully equivalent. ${ }^{132}$

This judgment was then subjected to an appeal which resulted in four separate appellate decisions being authored, demonstrating significant disagreement on the law on the defence of duress. ${ }^{133}$ Three of the five appellate judges concluded that duress does not afford a complete defence to a soldier charged with a crime against humanity and/or a war crime involving the killing of innocent human beings. In their attempt to discern general a principle of law, the judges observed that there was a "clear dichotomy in the practice of the main legal systems of the world'. ${ }^{134}$ In general, civil law

${ }^{129}$ Erdemović First Sentencing Judgment, ibid., para. 78.

${ }^{130}$ Ibid, at para. 10.

${ }^{131}$ Ibid, at para. 20.

${ }^{132}$ Ibid, at para. 19. The Trial Chamber does not explicitly refer to proportionality but emphasises that 'the violation here is no longer directed at the physical welfare of the victim alone but at humanity as a whole.' Judge Stephen of the Appellate Chamber frames these Trial Chamber statements as a question of proportionality which appears to be an accurate characterisation of the issue. Separate and Dissenting Opinion of Judge Stephen, Prosecutor v. Dražen Erdemović (IT-96-22-A), Appeals Chamber, 7 October 1997, at para. 13. ('Erdemović Appeal, Opinion of Judge Stephen'). It is worth noting, however, that the characterization of crimes against humanity as a crime against 'the whole of humankind' as relied upon by the Trial Chamber is disputed. See, e.g., Erdemović Appeal, Opinion of Judge Li, supra note 120, at para. 26.

${ }^{133}$ Erdemović Appeal Judgment, supra note 128. Judges McDonald and Vohrah wrote jointly and, together with Judge $\mathrm{Li}$ who submitted an individual opinion, constituted a majority on the question of the availability of the defence of duress (or lack thereof).

${ }^{134}$ Erdemović Appeal, Opinion of Judge McDonald and Judge Vohrah, supra note 109, at para. 32. Judge McDonald and Vohrah's assessment of general principles of law included a survey of domestic law with reference to 15 civil law jurisdictions, 7 common law countries, and 5 other countries, totaling 27 countries (including $3 \mathrm{AU}$ countries: Nigeria, Somalia and Ethiopia), at para. 63 . 
jurisdictions recognized duress as a possible defence to all crimes whereas common law jurisdictions rejected its availability for the crime of murder. ${ }^{135}$ Thus, Judges McDonald and Vohrah, in their joint decision concluded that there was a general principle of law 'that an accused person is less blameworthy and less deserving of the full punishment when he performs certain prohibited acts under duress. ${ }^{136}$ However, they concluded that there is no general agreement about whether duress is a complete defence to crimes involving killing. ${ }^{137}$

Discerning no customary international law or general principle with respect to the availability of the defence of duress to the killing of innocent people, the Majority judges turned to a normative analysis evaluating the availability of the defence of duress in the particular context of applying the defence at the ad hoc Tribunal. ${ }^{13^{8}}$ The judges emphasized the egregious nature of the crimes within the jurisdiction of the Tribunal, the vulnerability of civilians in times of armed conflict, and the increased likelihood of situations of persons being forced to commit atrocities under duress in times of conflict as opposed to in times of peace. ${ }^{139}$ The judgment of Judges McDonald and Vohrah also emphasized the fact that the accused was a soldier in the Bosnian Serb army. ${ }^{140}$ Pointing to certain domestic criminal codes which suggested that duress may not be available to soldiers participating in an armed conflict, they

135 Ibid, at para. 49.

${ }^{136}$ Ibid, at para. 66. Judge Li simply concluded that 'no general principle of law recognized by civilized nations can be deduced'. Erdemović Appeal, Opinion of Judge Li, supra note 120, at para. 3 .

${ }^{137}$ Erdemović Appeal, Opinion of Judge McDonald and Judge Vohrah, supra note 109, at para. 69. Judge Li concluded in his separate opinion supporting the majority: 'From a study of these decisions the following principles can be obtained: as a general rule, duress can be a complete defence. . To this general rule there is an important exception: if the act was a heinous crime, for instance, the killing of innocent civilians or prisoners of war, duress cannot be a complete defence, but can only be a ground of mitigation of punishment if justice requires.' Erdemović Appeal, Opinion of Judge Li, supra note 120, at para. 5. Judges McDonald and Vohrah also surveyed the post-World War II war crimes cases considered by the UNWCC and concluded that these authorities supported the exclusion of cases involving the killing of innocent persons from the scope of the defence of duress.' While recognizing that the Einsatzgruppen case did suggest that duress was an available defence to the killing of innocent persons, they ultimately concluded that 'the Einsatzgruppen decision is in discord with the preponderant view of international authorities.' At paras $52 \& 44$.

${ }^{13} 8$ Erdemović Appeal, Opinion of Judge McDonald and Judge Vohrah, ibid, at paras $72 \& 75$. Judge Cassese critiqued the Majority judges' approach, turning to 'policy considerations' to determine the question as inappropriate and 'extraneous to the task of our Tribunal.' Erdemović Appeal, Opinion of Judge Cassese, supra note 19, at para. 11.

139 Erdemović Appeal, Opinion of Judge McDonald and Judge Vohrah, ibid., at paras 75-6. See also Erdemović Appeal, Opinion of Judge Li, supra note 120, at para. 8.

${ }^{140}$ Erdemović Appeal, Opinion of Judge McDonald and Judge Vohrah, ibid., at para. 32. 
stated that 'soldiers or combatants are expected to exercise fortitude and a greater deal of resistance to a threat than civilians, at least when it is their own lives which are being threatened. Soldiers, by the very nature of their occupation, must have envisaged the possibility of violent death in pursuance of the cause for which they fight.'.11 Thus, they concluded that duress may be a mitigating factor in sentencing but could not be relied upon by a soldier charged with war crimes and crimes against humanity involving killing innocent persons. ${ }^{142}$

Judges Cassese and Stephens dissented from this view in individual separate and dissenting opinions. ${ }^{143}$ They both concluded that duress may constitute a complete defence under international criminal law without exceptions, provided that the strict requirements of the defence are established. ${ }^{144}$ They noted that the difficult questions surrounding the defence of duress in relation to offences involving killing would be dealt with in the proportionality assessment, suggesting that this proportionality requirement may not be met in relation to most cases involving killing. ${ }^{145}$ However, they emphasized the unique situation in which the victims would likely have been killed regardless. ' $[\mathrm{W}]$ here it is not a case of a direct choice between the life of the person acting under duress and the life of the victim - in situations, in other words, where there is a high probability that the person under duress will not be able to save the lives of the victims whatever he does - then duress may succeed as a defence. ${ }^{14^{6}}$ The majority, on the other hand, rejected this 'utilitarian' argument, asserting instead 'an absolute moral postulate' refusing to exclude responsibility for the killing of innocent persons. ${ }^{147}$

In Erdemović, a majority of the ICTY Appeals Chamber declined to recognize duress as a complete defence to war crimes or crimes against humanity involving killing. However, two strong dissenting opinions leave the status of international law on this issue unclear. The difficulty in

${ }^{141}$ Ibid., at paras $69 \&$ 84. This point was made with reference to German Law and the Penal Code of the former Socialist Federal Republic of Yugoslavia.

${ }^{142}$ Ibid., at paras $85 \& 88$.

${ }^{143}$ Erdemović Appeal Judgment, supra note 128, at para. 19.

144 Erdemović Appeal, Opinion of Judge Cassese, supra note 19, at paras 12 \& 44; Erdemović Appeal, Opinion of Judge Stephen, supra note 132, at paras 66-7. They also agreed that, when not accepted as a defence, it could be a mitigating factor on sentencing. See, e.g., Erdemović Appeal, Judge Cassese, supra note 19, at para. 12.

${ }^{145}$ Erdemović Appeal, Opinion of Judge Cassese, ibid., at para. 12.

${ }^{146}$ Ibid., at paras $12 \& 42$. See also Erdemović Appeal, Opinion of Judge Stephen, supra note 132, at para. 19.

147 Erdemović Appeal, Opinion of Judge McDonald and Judge Vohrah, supra note 109, at paras 79-93. See also Erdemović Appeal, Opinion of Judge Li, supra note 120, at para. 11. 
discerning a general principle of law on this question is a result of the diverging approaches taken in domestic systems, in particular as between civil law and common law systems. However, the law within domestic systems on these difficult questions may also continue to evolve. ${ }^{14^{8}}$ Thus, the African Court of Justice will have to give careful consideration to this question. It should, however, consider the fact that the Rome Statute, a treaty with 123 states parties of which, at present, 34 countries are from Africa, does not explicitly exclude any crimes from duress.

Article $31(1)(d)$ of the Rome Statute recognizes the defence of duress as a ground for excluding criminal responsibility at the ICC.

\section{Article $3_{1}$ Grounds for excluding criminal responsibility}

1. In addition to other grounds for excluding criminal responsibility provided for in this Statute, a person shall not be criminally responsible if, at the time of that person's conduct:

(d) The conduct which is alleged to constitute a crime within the jurisdiction of the Court has not been caused by duress resulting from a threat of imminent death or of continuing or imminent serious bodily harm against that person or another person, and the person acts necessarily and reasonably to avoid this threat, provided that the person does not intend to cause a greater harm than the one sought to be avoided. Such a threat may either be:

(i) Made by other persons or

(ii) Constituted by other circumstances beyond that person's control.

Whereas earlier drafts of the text enumerated necessity in a subparagraph (e), separate from duress, the provision adopted in Rome includes both the

${ }^{14^{8}}$ At least one common law jurisdiction has recently accepted that duress may be a defence to murder. In Canada, s.17 of the Criminal Code of Canada contains a codified version of the defence of duress which explicitly excludes murder amongst many other offences. Criminal Code, R.S.C., 1985, c. C-46. This provision is cited by Judges McDonald and Vohrah in Erdemović. Erdemović Appeal, Joint Separate Opinion of Judge McDonald and Judge Vohrah, ibid., at para. 6o. However, a common law defence of duress operates in Canada alongside the codified version (which applies to all those who are parties to the offence but do not commit the offence). Recently, in 2015, the Ontario Court of Appeal confirmed that the common law defence of duress in Canada is available for murder. R. v. Aravena, [2015] O.J. No. 1910. While the exclusion in the codified version of defence was not at issue in this case, the Ontario Court of Appeal remarked that 'the exception must be found unconstitutional.' (At para. 86). It can thus be expected that once the appropriate case comes before the courts, the exclusion of murder from the defence of duress in Canada will be overturned in full. 
defence of duress and the defence of necessity (in the form of 'duress of circumstances') in the same subsection. ${ }^{149}$

Whether crimes involving killing should be excluded outright or whether this consideration should be left to be evaluated as part of the proportionality assessment was one of the more difficult issues debated in drafting. ${ }^{150}$ Ultimately, the latter approach was adopted and Article $31(1)(d)$ does not exclude any offences outright, even offences involving killing.

What then are the elements of the defence of duress? As summarized by the UNWCC in its review of duress in the post-World War II cases, 'duress may prove a defence if (a) the act charged was done to avoid an immediate danger both serious and irreparable, (b) there was no other adequate means of escape, (c) the remedy was not disproportionate to the evil'. ${ }^{151}$ This formulation will be discussed below in comparison with the text of the Rome Statute, Article 31(1)(d).

The first element requires that one acts in response to an outside threat. This is articulated in Article $31(1)(d)$ of the Rome Statute as requiring that the duress resulted from a threat 'against that person or another person' which is 'made by other persons'. Thus, the threat may have been to the accused or to another person. ${ }^{152}$ No special relationship is required between the two individuals when the accused acts to avoid a threat to another person. ${ }^{153}$ The Rome Statute requires that the threat be 'of imminent death or of continuing or imminent serious bodily harm against the person or another person'. ${ }^{154}$ While the scope of crimes that fall within the jurisdiction of the African Court is of course much broader than that of the ICC, they are also all very serious and, therefore, a similarly high threshold may be warranted. ${ }^{155}$

Article $31(1)(d)$ also requires that the duress caused the commission of the crime. Thus, it has been suggested that an accused cannot avail themselves of

1491998 Report of the Preparatory Committee, supra note 20, at 35.

150 Saland, supra note 23 , at 208.

${ }^{151}$ UNWCC, Digest of Laws and Cases, supra note 9, at 174.

${ }^{152}$ In Rome, 'there were isolated calls for allowing this ground to be applied also in cases of threats against property' but this was ultimately rejected in favour of the high threshold ultimately adopted in the Rome Statute. Saland, supra note 23, at 208. Yeo argues that it would be entirely in keeping with [the current provision] to extend the defence to persons who were confronted with the destruction of property which is essential to their survival' which would also be in line with the provision on self-defence in Article 31(1)(c). Stanley Yeo, 'Compulsion and Necessity in African Criminal Law' 53 Journal of African Law (2009) 90, at 97.

153 Eser, supra note 18 , at 885 .

154 Supra note 21, Art. $32(1)(d)$.

155 It has been suggested that the high threshold set out in the Rome Statute is understandable given the very serious nature of the crimes falling within the jurisdiction of the International Criminal Court'. Stanley Yeo, 'Revisiting Necessity' 56 Crim. L. Q. (2010) 13, at 40. 
the defence of duress if the person would have committed the crime regardless of the threat. ${ }^{156}$ The relevant question is whether a 'reasonable person in comparable circumstances' would have been driven to commit the criminal conduct. ${ }^{157}$ It has been suggested that relevant individual characteristics of the accused should be considered in how the person could be expected to reasonably react in such circumstances..$^{15^{8}}$ This approach has been used to support the argument that a solider should be able to resist more danger and can, accordingly, be held to a higher standard than other people. ${ }^{159}$

There are also limitations on the way in which an individual can respond to such a threat in order to avail themselves of the defence of duress. First, the accused acting under duress must act necessarily. This is reflected in the requirement articulated by the UNWCC that 'there was no other adequate means of escape'. ${ }^{160}$ Furthermore, it also requires that the act was reasonable and/or proportionate. Whereas the majority of legal authorities refer to the requirement of proportionality in the accused's response to the threats, Article $31(1)(d)$ emphasizes that the accused must have acted reasonably. ${ }^{161}$ This criterion can be seen to incorporate the requirement of proportionality because an accused cannot be found to have acted reasonably if their acts were disproportionate to the harm threatened. ${ }^{162}$ This assessment of reasonableness and proportionality is where the most challenging questions surrounding the defence of duress arise, in particular in relation to crimes involving the taking of lives. The Rome Statute includes one additional requirement which is that 'the person does not intend to cause a great harm than the one sought to be avoided'. ${ }^{63}$ This additional requirement came about as a result of a compromise at the drafting in Rome but has been criticized as unnecessary and 'difficult to apply.' ${ }^{164}$

${ }^{156}$ Cryer et al., supra note 1 , at 408 .

157 Eser, supra note 18 , at 886.

${ }^{15^{8}}$ Yeo, 'Revisiting Necessity', supra note 155, at 44; Yeo, 'Compulsion and Necessity in African Criminal Law', supra note 152, at 96; Eser, ibid., at 886.

159 Eser, ibid. It is suggested that the test in such a case is 'best formulated as what would be considered necessary and reasonable by a service member of the experience and rank of the defendant.' Cryer et al., supra note 1, at 408.

${ }^{160}$ See also Yeo, 'Compulsion and Necessity in African Criminal Law', supra note 152, at 100; Cassese, International Criminal Law, supra note 1, at 281.

${ }^{161}$ For references to proportionality, see UNWCC, Digest of Laws and Cases, supra note 9, at 147; Thiam, 'Twelfth report on the draft Code', supra note 14, at 111; Erdemović Appeal, Opinion of Judge Cassese, supra note 19, at para. 16.

${ }^{162}$ Eser, supra note 18 , at $886-7$.

${ }^{163}$ Supra note 21, Art. 31(1)(d).

${ }^{164}$ Yeo, 'Compulsion and Necessity in African Criminal Law', supra note 152, at 102. 
It has also been suggested that a fourth element of an 'absence of prior fault' exists for duress. This means that the accused is precluded from relying on the defence of duress if the accused was culpable in creating the circumstances which gave rise to the threat under which they ultimately acted. ${ }^{165}$ It has been suggested that this requirement is part of customary international law 'and is consistent with national practice'. ${ }^{66}$ It has, accordingly, been suggested that 'duress or necessity cannot excuse from criminal responsibility the person who intends to avail himself of such defence if he freely and knowingly chose to become a member of a unit, organisation or group institutionally intent upon actions contrary to international humanitarian law. ${ }^{167}$ If accepted, this approach would not include conscripted armed forces. Furthermore, careful consideration should be given to the question of whether an individual joined freely, given that there are many coercive circumstances in times of armed conflict which may cause people to join armed groups. ${ }^{168}$ Furthermore, it would only apply to groups 'institutionally intent' upon violating international law. ${ }^{169}$ Thus, the mere fact of joining an armed group participating in an armed conflict does not meet this threshold. Given the fact that the African Court includes jurisdiction over transnational crimes as well as core international crimes, this limitation on the applicability of duress may be considered in relation to those who freely and knowingly join organized criminal groups. ${ }^{170}$

The defence of duress has been recognized in international criminal law and is codified in the Rome Statute. It may continue to be raised by accused in defence to charges of serious international and transnational crimes. There

165 This requirement is not explicitly referred to in the duress portion of Article $31(\mathrm{~d})$ of the Rome Statute. However, the necessity portion of Art. $31(\mathrm{~d})$ does refer to 'circumstances beyond that person's control'. Stanley Yeo, 'Compulsion and Necessity in African Criminal Law', ibid., at 105-7; Yeo, 'Revisiting Necessity', supra note 155, at 46. See also: Erdemović Appeal, Opinion of Judge Cassese, supra note 19, at para. 16; Thiam, "Twelfth report on the draft Code of Crimes', supra note 14, at 111; Cassese, International Criminal Law, supra note 1, at 284.

${ }^{166}$ Cryer et al., supra note 1, at 408, with reference to Judges Cassese and Stephen's decisions in Erdemović.

${ }^{167}$ Erdemović Appeal, Opinion of Judge Cassese, supra note 19, at para. 17.

${ }^{168}$ For instance, in the Erdemović case, the accused testified that he tried to avoid the war on many occasions but that he finally joined the Bosnian Serb army at least in part 'based on his need for money to feed himself and his wife.' Erdemović First Sentencing Judgment, supra note 42 , at para. 79 .

${ }^{169}$ Erdemović Appeal, Opinion of udge Cassese, supra note 19, at para. 17.

170 This approach is also taken in some domestic regimes. See, e.g., the Criminal Code of Canada, s.17 which states that a person may only be excused for acting under duress if the person is not a party to a conspiracy or association whereby the person is subject to compulsion'. Criminal Code, R.S.C., 1985 , c. C-46. 
remain uncertainties with respect to the boundaries of and potential exclusions from the defence of duress. However, even if no crime is explicitly excluded from the purview of duress, the strict requirements of the defence should limit its application and abuse.

\section{Necessity}

Throughout most of the drafting history of the Rome Statute, the defences of duress and necessity were listed as separate grounds for excluding criminal responsibility. ${ }^{171}$ However, in the final stages of drafting in Rome, duress and necessity were combined in one provision. ${ }^{172}$ While Article $31(1)(d)(i)$ includes the traditional defence of duress, subsection (ii), which refers to an accused who acts under duress '[c]onstituted by other circumstances beyond that person's control,' reflects one formulation of the defence of necessity. ${ }^{173}$ In other words, necessity is recognized in the form of the 'duress of circumstances'. ${ }^{174}$

Necessity is a less commonly recognized and less well defined concept than duress. ${ }^{175}$ However, it has been observed that ' $[t]$ he current trend is for the law to recognize a defence of necessity, the basic argument being that, insofar as criminal responsibility is concerned, there is no distinction between a person who committed an offence as a result of a threat by a human agent, and one who did so under a threat caused by natural circumstances. ${ }^{176}$

Necessity can be conceptualized in two different ways, as an excuse and as a justification. ${ }^{177}$ Necessity as a justification includes a situation where an accused acts and causes harm, but does so in order to avoid a greater harm. 'Justified necessity usually appeals to some version of choice of evils ... If the outcome "sought to be avoided" by the defendant is sufficiently grave compared to the defendant's act, then the act is justified by virtue of the necessity

\footnotetext{
${ }^{171}$ Eser, supra note 18 , at $883-4$.

${ }^{172}$ Eser, ibid.; Yeo, Revisiting Necessity', supra note 155, at 39.

${ }^{173}$ Yeo, 'Revisiting Necessity', ibid.

${ }^{174}$ Eser, supra note 18 , at 884 .

${ }^{175}$ Stanley Yeo conducted a comparative analysis focusing on four African criminal laws, South Africa, Gambia, Southern Nigeria, and Sudan, selected for their diversity of origin and "because their laws are representative of those of many other African nations. In this study, Yeo observed that "while all the criminal laws of the nations selected for this study recognize a defence of compulsion, only some recognize the defence of necessity. This is consistent with the development of these defences in other parts of the world as well as under international criminal law.' Yeo, 'Compulsion and Necessity in African Criminal Law', supra note 152, at 91. ${ }^{176}$ Ibid.

${ }^{177}$ See also Cassese, International Criminal Law, supra note 1, at 255-6 for a general discussion of the distinction between justifications and excuses.
} 
of the situation.' ${ }^{178}$ Necessity as an excuse resembles the defence of duress when the accused is compelled to commit an act which is criminal to avoid a serious threat emerging from external circumstances. ${ }^{179}$ In some national jurisdictions, both versions of the defence are recognized; whereas others recognize only one version and not the other. ${ }^{180}$

In addition to combining the defences of duress and necessity in Article $3^{1}$ $(\mathrm{l})(\mathrm{d})$, it has been suggested that this provision also combines elements of justification (the 'choice of a lesser evil') with elements of excuse (the absence of 'moral choice'). ${ }^{181}$ While some commentators approve of the combination of these defences in one paragraph, Article $31(1)(d)$ has been criticized by others for 'simply lump[ing] everything together in a muddle'. ${ }^{182}$ Similarly, some commentators have suggested that it is necessary to distinguish between the two different forms of necessity (as a justification versus an excuse). ${ }^{183}$ However, others suggest that this distinction is not necessary and the best approach is to develop a single formulation of necessity, which incorporates features of excuse and justification. ${ }^{184}$ Yeo, who advocates for the latter approach, emphasizes that 'the essential issue is whether the defendant's actions were, in the circumstances, blameworthy and deserving of condemnation and punishment. ${ }^{185}$

As discussed above, Article $31(1)(d)$ combines duress and necessity and, therefore, the elements of necessity under the Rome Statute are the same as those discussed above with respect to duress. However, there is one noteworthy difference. Article $31(1)$ (d)(ii) specifies that the defence of necessity is only available if the duress arises from 'circumstances beyond that person's control'. By contrast, no similar limitation is articulated in relation to duress under subsection (i). However, as discussed above, it has been suggested that the requirement of absence of prior fault should be applied to both duress and necessity.

${ }^{178}$ Ohlin, supra note 120, at 292. See also Thiam, 'Fourth report on the draft Code', supra note 12, at para. 194 .

${ }^{179}$ See Ohlin, ibid., at 292.

${ }^{180}$ Ibid., referencing the German Penal Code which codifies both versions and to the U.S. Model Penal Code which includes justified; Yeo, 'Revisiting Necessity', supra note 155, at 14-5, citing the Supreme Court of Canada's recognition of necessity as an excuse but rejecting it as a justification in R. v. Perka, [1984] 2 SCR 232.

${ }^{181}$ Eser, supra note 18 , at $883-4$; Ohlin, supra note 120 , at 293.

${ }^{182}$ Ohlin, ibid. See also Eser, ibid. On the other hand, Cassese says that the Rome Statute rightly lumps necessity and duress together'. Cassese, International Criminal Law, supra note 1, at 289.

${ }_{183}$ Ohlin, ibid.

${ }^{18} 4$ Yeo, 'Revisiting Necessity', supra note 155 , at 16.

185 Ibid., at 17 . 
Similar to the defence of duress, the question of whether any defences, such as murder, should be excluded from the application of the defence of necessity is often considered. ${ }^{186}$ In the context of the defence of necessity, the scholarly debate often focuses on whether or not it may be a defence to the crime of torture. ${ }^{187}$ While it is hopefully broadly accepted now that torture can never be justified, the question remains whether an individual could raise the defence of necessity as an excuse. ${ }^{188}$ This has led some to suggest that necessity should be ruled out as a possible defence for torture. ${ }^{189}$ The Rome Statute takes the approach of not explicitly excluding any crime and relies on the requirements that the act must be necessary and reasonable to restrict the defence.

The ICTY found that the defence of necessity existed in customary international law. ${ }^{190}$ The Tribunal contemplated that necessity may be a defence of justification to the war crime of plunder involving appropriation of property in time of famine if the following cumulative conditions are met: '(i) there must be a real and imminent threat of severe and irreparable harm to life existence, (ii) the acts of plunder must have been the only means to avoid the aforesaid harm, (iii) the acts of plunder were not disproportionate and (iv) the situation was not voluntarily brought about by the perpetrator himself. ${ }^{1{ }^{11}}$ The ICC in Katanga contemplated the possibility that circumstances comparable to famine may amount to necessity under article 31(1)(d) of the Rome Statute but did not find that such extreme circumstances were made out on the facts of that case. ${ }^{192}$ In the ICTY case Prosecutor v. Naser Orić, the Trial Chamber did conclude that the defence of necessity was available in relation

${ }^{186}$ See, e.g., Yeo, 'Revisiting Necessity', ibid.; Yeo, 'Compulsion and Necessity in African Criminal Law', supra note 152, at 104-5.

${ }^{187}$ See, e.g., Ohlin, supra note 120; Paola Gaeta, 'May Necessity Be Available as a Defence for Torture in the Interrogation of Suspected Terrorists?' 2 Journal of International Criminal Justice (2004) 785 .

${ }^{188}$ Ohlin emphasises that the focus of the analysis in this context should be on necessity as an excuse. Ibid.

${ }^{189}$ See, e.g., Gaeta, 'May Necessity Be Available as a Defence for Torture in the Interrogation of Suspected Terrorists?', supra note 187, at 793 . However, Gaeta suggests that, factually, necessity would not be successful as a defence for the paradigmatic hypothetical 'ticking time bomb' torture scenario because such an act of torture could never be necessary and reasonable. (At 791-2).

${ }^{19 \circ}$ Oral decision pursuant to Rule 98bis, Prosecutor v. Naser Orić (IT-03-68-T), Trial Chamber, 8 June 2005, Transcript at p. 9027, lines 10-13 ('Orić decision').

${ }^{191}$ Judgment, Prosecutor v. Hadžihasanović and Kubura (IT-o1-47-T), Trial Chamber, 15 March 2006 , at paras $53 \& 56$. No such claim was, however, made on the facts in this case (see paras 1854-1993). See also Orić decision, ibid. at page 9027, lines 6-20.

${ }^{192}$ Judgment pursuant to article 74 of the Statute, Prosecutor v. Katanga (ICC-o1/04-01/07-3436tENG), Trial Chamber, 7 March 2014, paras 955-6 ('Katanga Trial Judgment'). 
to charges of plunder involving the theft of cattle in the situation of a city under siege and a starving population. ${ }^{193}$

In another ICTY case, the accused, the commander or prison warden of a detention facility, attempted to raise the defence of necessity in response to convictions for war crimes relating to the mistreatment of civilian detainees. ${ }^{194}$ On appeal, the convicted prison warden argued that the conduct was justified by necessity because more people were injured and killed outside of the facility due to the armed conflict than inside the prison. He suggested that the defence of necessity 'excludes the perpetrator's unlawful actions since such actions are motivated by the intent to avoid a worse violation.' ${ }^{\prime 95}$ The Appeals Chamber rejected the argument as misplaced on the facts of the case. ${ }^{196}$

In the Special Court for Sierra Leone's ('SCSL') CDF Trial, one trial judge concluded the defence of necessity was available to the accused who were fighting on behalf of the democratically ousted government which had been ousted by a coup 'on the grounds that the preservation of democratic rule is a vital interest worth protecting at all cost in the face of rebellion, anarchy and tyranny'. ${ }^{197}$ However, this was unsurprisingly rejected by the other two trial judges. ${ }^{198}$

The version of necessity codified in the Rome Statute is the more restrictive excuse of necessity, in the sense of an accused acting under compulsion from 'duress of circumstances' ${ }^{199}$ The African Court could follow this lead and take a similarly restrictive approach. Additionally, even if no crimes are explicitly excluded, the requirements that the act be necessary, reasonable and proportionate would likely prevent the success of the defence in all but the most

193 Orić decision, supra note 190, at pp. 9029-31.

194 Judgment, The Prosecutor v. Zlatko Aleksovski (IT-95-14/T), Trial Chamber, 25 June 1999, paras $5,20-4,27,34,93,221-9$.

195 Judgment, Prosecutor v. Zlatko Aleksovski, Appeals Chamber, (IT-95-14/1-A) 24 March 2000, paras 39-40 ('Aleksovski Appeal Judgment').

196 Accordingly, the Appeals Chamber in that case concluded that it was 'unnecessary to dwell on whether necessity constitutes a defence under international law [and] whether it is the same as the defence of duress.' Aleksovski Appeal Judgment, ibid., at para. 52-6.

197 Judgment, Prosecutor v. Fofana and Kondewa, (SCSL-04-14-T), Trial Chamber I, 2 August 2007, Annex C - Separate Concurring and Partially Dissenting Opinion of Hon. Justice Bankole Thompson, para. ${ }_{9}$ ('CDF Trial Judgment - Dissenting Opinion of Justice Thompson'). See also paras 68-88.

${ }^{198}$ Judgment on the Sentencing of Moinina Fofana and Allieu Kondewa,, Prosecutor v. Fofana and Kondewa (SCSL-04-14-T), Trial Chamber I, 9 October 2007, paras 70-81 ('CDF Sentencing Judgment').

199 However, it has been suggested that necessity as a justification could be recognized under Article 31(3). Ohlin, supra note 120, at 293. 
exceptional cases. This is demonstrated by the limited relevance of the defence thus far in the international criminal law jurisprudence.

\section{E. Mistake of Fact and Mistake of Law}

In addition to the grounds for excluding criminal responsibility included in the Rome Statute as discussed above, Article 32 of the Rome Statute also includes the following provision on the defences of mistake of fact and mistake of law:

\section{Article 32}

1. A mistake of fact shall be a ground for excluding criminal responsibility only if it negates the mental element required by the crime.

2. A mistake of law as to whether a particular type of conduct is a crime within the jurisdiction of the Court shall not be a ground for excluding criminal responsibility. A mistake of law may, however, be a ground for excluding criminal responsibility if it negates the mental element required by such a crime, or as provided for in article 33 .

Mistakes of fact or mistake of law were often raised by the accused tried pursuant to the Nuremberg Charter and Control Council Law No. 10, despite these instruments' silence on these defences. ${ }^{200}$ In this post-World War II jurisprudence, mistake of fact was accepted as a defence but exculpatory arguments about mistake of law were generally rejected. ${ }^{201}$

The defence of mistake of fact is uncontroversial because a mistake about the nature of any material fact would preclude a finding of the required mens rea. For example, if an individual attacked a building believing it with good reason to be a legitimate military objective, they would lack the mens rea for the war crime of attacking a civilian object, even if the accused's belief as to the nature of the building was mistaken and it was in fact a civilian object. Thus, the UNWCC observed that "mistake of facts ... may constitute a defence in war crimes trials just as it may in trials before municipal courts. ${ }^{202}$ This is sometimes referred to as a failure of proof defence.

${ }^{200}$ Otto Triffterer, 'Article 32 - Mistake of fact or mistake of law' in Otto Triffterer (ed.), Commentary on the Rome Statute of the International Criminal Court, (2nd edn. Munich:

C. H. Beck, 2008) 895, at 897 ('Article 32').

${ }^{201}$ Ibid.

${ }^{202}$ UNWCC, Digest of Laws and Cases, supra note 9, at 184. 
It was questioned during the drafting whether it was actually necessary to include these defences in the Rome Statute at all. ${ }^{203}$ To the extent that these defences amount to a negation of the mental element, they do not need to be explicitly enumerated because, if established, the mental element for the crime would be absent and an accused would clearly not be criminally culpable. Thus, the first paragraph of Article 32, which recognizes mistake of fact 'only if it negates the mental element required by the crime,' has been described as merely stating what is otherwise 'self-evident' and amounting to no more than 'a pure clarification of a generally accepted principle of criminal law' ${ }^{204}$

While mistake of fact is readily accepted, the defence of mistake of law is more controversial. ${ }^{205}$ While it is generally a rule of national jurisdictions that ignorance of the law is no excuse to criminal responsibility, some have argued that individuals may not be expected to be as knowledgeable about international law as they are about their national laws. ${ }^{206}$ Thus, it is suggested that a defence of mistake of law, in the sense of a mistaken belief that something is lawful when it is not, may be more justifiable in relation to prosecutions for international crimes. ${ }^{207}$ This argument, however, is generally limited to the confines of war crimes because other international crimes including crimes against humanity and genocide are obviously unlawful and no person can reasonably be under a mistaken belief in their legality. ${ }^{208}$ The same would hold true for many war crimes as well. ${ }^{209}$ Furthermore, international humanitarian law places obligations on states to educate their armed forces about the law of armed conflict thus reducing the persuasiveness of this argument. ${ }^{210}$

203 Triffterer, 'Article 32', supra note 200, at 899-900; Saland, supra note 23, at 210; 1996 Report of the Preparatory Committee, Vol. I, supra note 20, at para. 205.

204 Triffterer, ibid., at 900.

${ }^{205}$ Eser says that mistake of law is 'worldwide [a] highly controversial ground for excluding criminal responsibility.' Eser, supra note 18 , at 868 .

${ }^{206}$ UNWCC, Digest of Laws and Cases, supra note 9, at 182; Dinstein, supra note 1, paras 11-13.

${ }^{207}$ Special Rapporteur D. Thiam, 'Fourth report on the draft Code of Offences against the Peace and Security of Mankind,' Document A/CN.4/398 (11 March 1998) in Yearbook of the International Law Commission 1986, Volume II, Part I (New York: United Nations, 1998), UN Doc. A/CN.4/SER.A/1986/Add.1 (Part 1), at paras 207-8.

${ }^{208}$ Thiam, 'Fourth report on the draft Code', supra note 12, at paras 209 \& 211; Dinstein, supra note 1 , at paras $11-13$.

209 Thiam, 'Fourth report on the draft Code', ibid., atparas 209 \& 211; Dinstein, ibid., at paras $11-13$.

${ }^{210}$ For example, all four 1949 Geneva Conventions include obligations on states to disseminate the Conventions, in particular to military personnel. For example, Article 144 of Geneva Convention IV states: "The High Contracting Parties undertake, in time of peace as in time of war, to disseminate the text of the present Convention as widely as possible in their respective countries, and, in particular, to include the study thereof in their programs of military and, if 
Ignorance of the law is not, however, recognized as a defence in Article $32(2)$ of the Rome Statute. This provision explicitly states that '[a] mistake of law as to whether a particular type of conduct is a crime within the jurisdiction of the Court shall not be a ground for excluding criminal responsibility.' Accordingly, it is unlikely that it would be generally accepted today that ignorance of the law, even of international law, would constitute a defence to serious international or transnational crimes. ${ }^{211}$

The version of mistake of law that is included in the Rome Statute is quite limited. ${ }^{212}$ Article $32(2)$ only recognises the defence of mistake of law, outside of the defence of superior orders pursuant to Article 33 of the Rome Statute, in the limited circumstances in which it negates the mental element required by such a crime'. This limited defence only applies when there is a 'wrongful legal evaluation' or a 'mistake of legal element'. ${ }^{213}$ Thus, as described by Heller, the defence of mistake of law as defined in the Rome Statute amounts to an argument that the accused 'was mistaken concerning the definition of a legal element in a crime such that he cannot be said to have acted 'knowingly' with regard to that element. ${ }^{214}$ This can arise in particular in relation to war crimes which often involve reference to international humanitarian law to legally evaluate some of the material elements of the war crimes proscribed by the Rome Statute. ${ }^{215}$

As an example of a crime with a legal element, Heller points to the crime against humanity of 'Imprisonment or other severe deprivation of physical liberty in violation of fundamental rules of international law. ${ }^{216}$ Another example pointed to by commentators is the war crime of using weapons or

possible, civilian instruction, so that the principles thereof may become known to the entire population. Any civilian, military, police or other authorities, who in time of war assume responsibilities in respect of protected persons, must possess the text of the Convention and be specifically instructed as to its provision.' Supra note 270. Such an obligation has long been a part of international humanitarian law. For example, 1907 Hague Convention IV obligates states, in its initial provision, to issue instructions to their armed land forces which shall be in conformity with the Regulations respecting the laws and customs of war on land, annexed to the present Convention.' 1907 'Hague Convention IV Respecting the Laws and Customs of War on Land', Art. 1, in Roberts and Guelff (eds.), Documents on the Laws of War, (3rd ed. Oxford: Oxford University Press, 2000) 69 at 70.

${ }^{211}$ See for example, Cassese, International Criminal Law, supra note 1, at 294.

${ }^{212}$ See Triffterer, 'Article 32', supra note 200, at 900-3 and 906-7.

${ }^{213}$ Ibid at 908. Kevin Jon Heller, 'Mistake of Legal Element, the Common Law, and Article 32 of the Rome Statute: A Critical Analysis' 6 Journal of International Criminal Justice (2008) 419-45.

${ }^{214}$ Heller, ibid., at 423 .

${ }^{215}$ For example, Heller defines a 'legal element' as 'an element whose definition depends on a legal source other than the Rome Statute itself. Ibid., at 422 .

${ }^{216}$ Rome Statute, supra note 21, at Art. 7(1)(e) [emphasis added]. See Heller, ibid., at 422. See also Triffterer, 'Article 32 ', supra note 100, at 902. 
methods of warfare which cause superfluous injury or are inherently indiscriminate "provided that such weapons, projectiles and material and methods of warfare are the subject of a comprehensive prohibition' pursuant to Article 8 (2)(b)(xx) of the Rome Statute. ${ }^{217}$

The potential scope of the more restrictive version of mistake of law adopted in the Rome Statute is disputed amongst scholars. It has been suggested by some that this narrowly defined defence of mistake of law will have limited relevance with respect to international crimes. This view is based on the argument that it has generally been accepted that the mental element of most international crimes requires only awareness of the existence of the material facts and not a legal evaluation of the facts. For example, according to the Elements of Crimes, for prosecutions of war crimes pursuant to the Rome Statute, "[t]here is no requirement for a legal evaluation by the perpetrator as to the existence of an armed conflict or its character as international or noninternational'. ${ }^{218}$ Accordingly, the final element of each war crime requires only that " $\mathrm{t}$ ] he perpetrator was aware of the factual circumstances that established the existence of an armed conflict. ${ }^{219}$ This approach limits the potential scope of the mistake of law defence because no legal analysis is required. Heller, on the other hand, argues that Article 32(2) has broader application than is generally recognized. ${ }^{220}$ Ultimately, the potential scope of this defence depends on the degree to which the Court accepts these 'factual awareness elements' as being consistent with the mental element requirements defined in Article 30 of the Rome Statute. ${ }^{221}$ If accepted, these factual awareness elements, in particular in relation to the contextual elements of international

${ }^{217}$ Triffterer, ibid., at 907. Heller summarizes some of the other war crimes that have been referred to in the scholarship as potentially open to a legitimate claim of mistake of legal element. Heller, ibid., at 425 .

${ }^{218}$ Art. 8 - War Crimes - Introduction. Elements of Crimes, Official Records of the Assembly of States Parties to the Rome Statute of the International Criminal Court, First Session, New York, 3-10 September 2002 (United Nations publication, Sales No. E.03.V.2 and corrigendum), part II.B.

${ }^{219}$ Ibid. Similarly, for every war crime pursuant to Art. 8(2)(a) of the Rome Statute, which are Grave breaches of the Geneva Conventions, the Elements of Crimes specify that all that is required is that " $\mathrm{t}]$ ]he perpetrator was aware of the factual circumstances that established that protected status' and, therefore, are not required to be aware of the legal evaluation of such protected status.

${ }^{220}$ Heller, supra note 213, at $421 \& 430$. [Emphasis added]

${ }^{221}$ Heller suggests that these 'factual awareness elements' are inconsistent with Arts 30 and $32(2)$ and, therefore, that mistake of legal element has a potentially very broad impact. Ibid., at $433-4$. The Court has, however, accepted the 'factual awareness element' with respect to the contextual element for war crimes which only requires an awareness of the 'factual circumstances that established the existence of an armed conflict' and not any legal evaluation thereof, thus limiting the potential scope of Article 32(2). See, e.g., Judgment pursuant to 
crimes, will seriously reduce the practical availability of claims of mistake, in particular given the widespread and large scale nature of international crimes and the visible nature of their perpetration which would make it unlikely that an individual would have a legitimate claim that they were unaware of such facts. ${ }^{222}$

Pursuant to the approach taken in the Rome Statute, a mistake, whether it be a mistake of fact or a mistake of law on the occasion in which a legal evaluation of a situation is a material element, can amount to a defence by negating mens rea. However, it has been pointed out that the word mistake may be misleading in that it suggests a 'false perception of reality', whereas an individual who is ignorant as to the reality may similarly lack the mens rea. ${ }^{223}$ Thus, 'error and mistake as well as lack of knowledge and awareness' can give rise to a mistake of fact or mistake of legal element defence. ${ }^{224}$

It has, however, been suggested that it would not be a defence to a crime requiring discriminatory intent (for example, genocide or persecution as a crime against humanity) for an accused to say that they were mistaken in their belief of the characteristics of a particular victim. 'A person who mistakes the religion or race of a victim may not invoke this error as a defence, since the motive for his act was, in any case, of a racial or religious nature. ${ }^{.225}$ Similarly, Bantekas submits that mistake should not apply if an accused intends to kill one individual, but mistakes another person for that individual, since the act was still committed with the mens rea of murder. ${ }^{226}$ Along this line of reasoning, an accused may not avail themselves of a mistake of fact defence for a charge of crimes involving illicit narcotics if they were mistaken about the particular substance that they were trafficking (i.e. if they thought that they were trafficking one illicit substance but were mistaken and it turned out to be a different illicit substance). In such a case, the act would not have been lawful regardless of the mistake. ${ }^{27}$

Article 74 of the Statute, Prosecutorv. Thomas Lubanga Dyilo (ICC-o1/04-o1/o6-2842), Trial Chamber I, 14 March 2012, at paras 1016 \& 1018 ('Lubanga Trial Judgment').

${ }^{222}$ Based on this argument, Triffterer suggests that the defences of mistake will be of 'limited practical importance' for core international crimes. Triffterer, 'Article 32', supra note 200, at 909 .

${ }^{223}$ Ibid., at 903 .

${ }^{224}$ Ibid., at 903 \& 906.

225 Thiam, 'Fourth report on the draft Code', supra note 12, at para. 214.

${ }^{226}$ Bantekas, supra note 1, at $115-6$.

227 According to Triffterer, early drafts for an international criminal court by the Association Internationale de Droit Pénal (AIDP) and the International Law Association (ILA) considered the defence of mistake when there was a negation of 'the mental element required by the crime charged provided that said mistake is not inconsistent with the nature of the crime or its 
Even without any explicit reference to the defence of mistake in the Malabo Protocol, mistakes of both fact and law (in the narrow sense of a mistake with respect to a material element which requires a legal characterization) will be a relevant exculpatory factor when it negates the mental element of the crime. The breadth of the mistake of law defence, in particular, will depend on how exactly the mental elements of the crimes are defined. On the other hand, it seems to be less accepted that a mistake of law, in the sense of ignorance of the unlawfulness of the conduct, is a defence, even for international crimes.

\section{F. Exclusion of the Superior Orders Defence}

While the Mabalo Protocol does not include an enumerated list of the defences it will recognize, Article $46 \mathrm{~B}$ on Individual Criminal Responsibility is significant because it explicitly excludes the defence of superior orders. Pursuant to Article $46 \mathrm{~B}(4)$ : "The fact that an accused person acted pursuant to an order of a Government or of a superior shall not relieve him or her of criminal responsibility, but may be considered in mitigation of punishment if the Court determines that justice so requires. ${ }^{228}$ This exclusion of the defence of superior orders reflects a return to the position adopted at Nuremberg and followed by the ad hoc international criminal tribunals. ${ }^{229}$ It has been suggested by some that the exclusion of the defence of superior orders for international crimes amounts to customary international law. ${ }^{230}$

According to the UNWCC writing after World War II: "The plea of superior orders has been raised by the Defence in war crimes trials more

elements, and provided that the circumstances he reasonably believed to be true would have been lawful'. [Emphasis added] Triffterer, 'Article 32', supra note 200, at 898 .

${ }^{228}$ Draft Protocol on the Amendments to the Protocol on the Statute of the African Court of Justice and Human Rights, as at Thursday 15 May 2014, STC/Legal/Min/7(I) Rev.1, P.35, Article $46 \mathrm{~B}(4)$.

${ }^{229}$ For further discussion of the defence of superior orders, see: Paula Gaeta, "The Defence of Superior Orders: The Statute of the International Criminal Court versus Customary International Law' 10 European Journal of International Law (1999) 172; Otto Triffterer, 'Article 33 - Superior Orders and prescription of law' in Otto Triffterer (ed.), Commentary on the Rome Statute of the International Criminal Court, (2nd edn. Munich: C.H. Beck, 2008) 915 ('Article 33'); Andreas Zimmermann, 'Superior Orders' in Cassese et al. (eds), The Rome Statute of the International Criminal Court: A Commentary, Vol. 1 (Oxford: Oxford University Press, 2002) at 957-74; Jeanne L. Bakker, "The Defence of Obedience to Superior Orders: The Mens Rea Requirement' 17 Am. J. Crim. L. (1989-1990) 55; Hilaire McCoubrey, 'From Nuremberg to Rome: Restoring the Defence of Superior Orders' 50 ICLQ (2001) 386.

${ }^{230}$ Cassese, International Criminal Law, supra note 1, at $258 \&$ 270. Other commentators are less convinced that this position represents customary international law. See, e.g., Zimmermann, ibid. at 965; McCoubrey, ibid., at 390-1. 
frequently than any other. ${ }^{231}$ Historically, in many states, the fact that an individual acted pursuant to a superior order could be relied upon to exclude criminal responsibility for the acts carried out. ${ }^{232}$ Responsibility would lie, instead, upon the commander who issued the unlawful order (known as the principle of respondeat superior). ${ }^{233}$ In the few trials that followed World War I, however, an individual was precluded from relying upon the defence of superior orders if the order was manifestly unlawful or the accused was aware of the unlawfulness of the order. ${ }^{234}$

The defence of superior orders was rejected in Article 8 of the Charter of the International Military Tribunal ('Nuremberg Charter'). ${ }^{235}$ This approach was followed in the Charter of the Military Tribunal for the Far East (the Tokyo Charter) and in Control Council Law No. 10. ${ }^{236}$ At most, the plea of superior orders may have been considered in sentencing as a mitigating factor. ${ }^{237}$ The Nuremberg approach was followed, in substantively similar terms, in the statutes of the ICTY (Article 7(4)), ${ }^{238}$ the ICTR (Article 6(4)), ${ }^{239}$ the SCSL (Article 6(4)), ${ }^{24}$ and the Extraordinary Chambers of the Courts of Cambodia (Article 29). ${ }^{241}$

${ }^{231}$ UNWCC, Digest of Laws and Cases, supra note 9, at 157.

${ }^{232}$ Cassese, International Criminal Law, supra note 1, at 269.

233 Ibid.

${ }^{234}$ See, e.g., Judgment in the Case of Lieutenants Dithmar and Boldt (Hospital Ship 'Llandovery Castle'), German War Trials, Supreme Court at Leipzig, 16 July 1921, reprinted in 16 Am.

J. Int'l L. (1922) 708. See also Gaeta, 'The Defence of Superior Orders', supra note 23, at 175.

${ }^{235}$ Charter of the International Military Tribunal, Annexed to the Agreement for the Prosecution and Punishment of the Major War Criminals of the European Axis, 8 August 1945, reprinted in 39 Am. J. Int'l L. 257 (Supp. 1945).

${ }^{236}$ Charter of the International Military Tribunal for the Far East, Bevans, C. (ed), Treaties and Other International Agreements of the United States of America 1776-1949, Vol. 4, p.21, 26 April 1946; Article 6; Control Council Law No. 10, 20 December 1945; Official Gazette of the Control Council for Germany, No. 3, Berlin, 31 January 1946; Trials of War Criminals before the Nuremberg Military Tribunal under Control Council Law No. 10, Volume 1, p.xvii, Art. 4(b).

${ }^{237}$ UNWCC, Digest of Laws and Cases, supra note 9 at 155.

${ }^{23^{8}}$ Statute of the International Criminal Tribunal for the former Yugoslavia, Annexed to the Report of the Secretary-General pursuant to paragraph 2 of Security Council 808 (1993), UN Doc. S/ 25704, adopted on 25 May 1993 ('ICTY Statute').

239 Statute of the International Criminal Tribunal for Rwanda (as amended), 31 January 2010, available online at: http://unictr.unmict.org/sites/unictr.org/files/legal-library/100131_Statute_ en_fr_o.pdf ('ICTR Statute').

${ }^{24}$ Statute of the Special Court for Sierra Leone (as amended), annexed to the Agreement Between the United Nations and the Government of Sierra Leone on the Establishment of a Special Court for Sierra Leone (16 January 2002).

${ }^{241}$ Law on the Establishment of the Extraordinary Chambers in the Courts of Cambodia for the Prosecution of Crimes Committed During the Period of Democratic Kampuchea, with inclusions of amendments as promulgated on 27 October 2004 (NS/RKM/1004/oo6). 
On the other hand, Article 33(1) of the Rome Statute recognizes the defence of superior orders if: "(a) The person was under a legal obligation to obey orders of the Government or the superior in question; (b) The person did not know that the order was unlawful and (c) The order was not manifestly unlawful. ${ }^{242}$ This approach reflects a departure from the more robust prohibition on the reliance on the superior orders defence in the Nuremberg Charter and the ad hoc international criminal tribunals and has been criticized accordingly. ${ }^{243}$ However, in practice it opens up only a very small door to the defence of superior orders and it is unlikely in practice to be applicable in many (or, perhaps, in any) prosecutions before the ICC. This is the case for a number of reasons.

First, pursuant to subsection (2) of Article 33, all acts of genocide or crimes against humanity are manifestly unlawful. Therefore, an individual is precluded from relying on the defence of superior orders for all charges of crimes against humanity and genocide. Thus, the scope of the superior orders defence is restricted to charges of war crimes. ${ }^{244}$ Second, many of the war crimes included in the Rome Statute, such as torture, rape or other forms of sexual violence, amongst many others, would be manifestly unlawful like crimes against humanity and genocide. ${ }^{245}$ Finally, the Rome Statute's departure from the Nuremberg prohibition on superior orders is not likely to result

${ }^{242}$ Rome Statute, supra note 21, Art. 33(1).

${ }^{243}$ Gaeta, 'The Defence of Superior Orders', supra note 229, at 190; Antonio Cassese, 'The Statute of the International Criminal Court: Some Preliminary Reflections' 10 EJIL (1999) 144 at $156-157$.

244 The crime of aggression is not explicitly listed as inherently manifestly unlawful pursuant to Art. 33(2) of the Rome Statute. However, if the ICC does at some future point in time secure jurisdiction over the crime of aggression, the defence of superior orders is not likely to be relevant to charges of aggression given the leadership clause in Art. 8 bis (1) of the Rome Statute's definition of aggression, which states that: 'For the purposes of this Statute, "crime of aggression" means the planning, preparation, initiation or execution, by a person in a position effectively to direct the political or military action of a State, of an act of aggression which, by its character, gravity and scale, constitutes a manifest violation of the Charter of the United Nations.' (emphasis added) Therefore, prosecutions for the crime of aggression are limited to those most senior leaders, and not subordinates who could allege that they were acting pursuant to orders.

${ }^{245}$ Some commentators have suggested the possibility that all war crimes are manifestly unlawful. See, e.g., Gaeta, 'The Defence of Superior Orders', supra note 23, at 185-186 \& 190-191. However, the better definitions interpret manifestly unlawful as meaning that 'the illegality was "obvious to a person of ordinary understanding"'. Zimmerman, supra note 229, at 970 citing a 1942 unpublished memorandum by Lauterpacht. Thus, 'manifest' means 'obvious' and there are a number of war crimes where the illegality might not be obvious if, for example, an individual is acting under mistaken information about the nature of an object of attack. Thus, war crimes which may not be 'manifestly' unlawful could include prohibitions against attacking certain objects with certain protections (such as the prohibition against attacking 
in many acquittals because, due to limited resources, the Prosecutor of the ICC has often focused investigations and prosecutions on senior leaders including sitting and former heads of state and senior commanders of nonstate armed groups. Therefore, it is more likely that those individuals giving the orders will be prosecuted rather than those acting pursuant to orders.

Despite the fact that the approach taken in Article 33 of the Rome Statute is unlikely to change the outcome of many cases in practice, the African Court's complete exclusion of the defence of superior orders reflects a return to the position of the Nuremberg Charter (which also excluded a plea of official capacity) and the majority of the other international criminal courts and tribunals. Given the African Court's broad subject matter jurisdiction and the fact that the African Court may not be so limited in only prosecuting those most senior leaders, this return to the Nuremberg approach will likely be welcomed given that the defence of superior orders has been described as 'highly controversial'. ${ }^{246}$ Other defences, including mistake of fact and duress which may factually arise in circumstances where an accused is acting under the orders of a superior, should be recognized by the court. ${ }^{247}$ These defences will adequately ensure that criminal responsibility of individuals acting pursuant to superior orders only attaches to those with the requisite degree of fault.

\section{G. Other Potential Defences Relating to War Crimes}

The final subsection of Article 31 of the Rome Statute makes it clear that the explicit inclusion of certain defences, such as mental disease or defect, intoxication, defence of persons and property, and duress, is not exhaustive. Article 31(3) states that: 'At trial, the Court may consider a ground for excluding criminal responsibility other than those referred to in paragraph 1 where such ground is derived from applicable law as set forth in article $21 .{ }^{248}$ This provision was included because the drafters felt that the Rome Statute could

civilian objects) where the knowledge about whether or not the object is entitled to such protection may potentially lie only with those higher up the chain of command.

${ }^{246}$ Eser, supra note 18 , at 868 . Gaeta has also described the defence of superior orders as 'one of the most widely debated and controversial defences in international criminal law.' Gaeta, 'The Defence of Superior Orders', supra note 229, at 173.

247 Triffterer, 'Article 33', supra note 229, at 920.

${ }^{24} 8$ The sources of applicable law referred to in Art. 21 of the Rome Statute, beyond the Statute, Elements of Crimes and Rules of Procedure of the Court itself, include: 'applicable treaties and rules of international law, including the established principles of the international law of armed conflict' and 'general principles of law derived from the Court from national laws of legal systems of the world including, as appropriate, the national laws of the States that would normally exercise jurisdiction over the crime'. 
not possibly foresee all situations and that respect for the rights of the indicted made it necessary to have such a "window". 249 In particular, this "window" replaced a draft article on defences under public international law, subsequently changed to 'possible grounds for excluding criminal responsibility referring to war crimes. ${ }^{250}$ This provision existed as a 'place-holder', without any attached text to it, throughout the process of negotiations. ${ }^{251}$ This draft article on defences applicable to war crimes contemplated the inclusion of military necessity, reprisals and, possibly, self-defence under Article 51 of the UN Charter. ${ }^{252}$ However, this draft provision was ultimately omitted from the final text of the Rome Statute because political agreement on definitions of these defences was considered 'almost impossible'. ${ }^{253}$

While Article 51 self-defence and its relationship to the crime of aggression are beyond the scope of this chapter, as is a detailed examination of the rules of international humanitarian law, this section of the chapter will briefly consider potential defences which have been discussed in the international criminal jurisdiction in relation to war crimes, including: military necessity, reprisals, tu quoque, and defensive operations. Some of these defences may still have limited applicability to certain war crimes. However, others have been explicitly rejected by the courts and are inapplicable today.

\section{Military Necessity}

The UNWCC observed that the plea of military necessity was often raised during the post-World War II war crimes trials alongside the pleas of superior orders and of duress. ${ }^{254}$ Both the ICC and the ICTY have adopted the definition of military necessity from article 14 of the Lieber Code of 1863 which states that 'Military necessity [...] consists in the necessity of those measures which are indispensable for securing the ends of the war, and which are lawful according to the modern law and usages of war'. ${ }^{255}$

\footnotetext{
249 Saland, supra note 23, at 209.

$25^{\circ}$ Saland, ibid,. See 1996 Report of the Preparatory Committee, Vol. II, supra note 27, at 27; 1998 Report of the Preparatory Committee, supra note 20, at 35.

${ }^{251}$ Saland, ibid. See 1996 Report of the Preparatory Committee, Vol. II, ibid.; 1998 Report of the Preparatory Committee, ibid.

${ }^{252}$ Saland, ibid. See 'Report of the Ad Hoc Committee', supra note 17, Annex 1 at 59-60; 1996 Report of the Preparatory Committee, Vol. II, ibid.

253 Saland, ibid.

${ }^{254}$ UNWCC, Digest of Laws and Cases, supra note 9 at 156.

255 Instructions for the Government of Armies of the United States in the Field, General Orders No. 100 (1863) ('Lieber Code'). See Katanga Trial Judgment, supra note 204, at para. 894; Judgment, Prosecutor v. Kordić and Čerkez, (IT-95-14/2-A), Appeals Chamber, 17 December 2004, para. 686.
} 
As stated by the UNWCC, the position generally taken by the post-World War II tribunals was that ' $[\mathrm{m}]$ ilitary necessity or expediency do not justify a violation of positive rules' and, accordingly, military necessity was only relevant when the applicable laws of armed conflict explicitly stated so. ${ }^{256}$ In other words, military necessity may not be invoked as a defence as such and, therefore, is only relevant when explicitly contemplated within the definition of the war crime itself. ${ }^{257}$ The ICC has taken this approach and in one case declared that military necessity can 'in no circumstances' be a defence to the prohibition against targeting attacks against civilians. ${ }^{258}$

In the Malabo Protocol, reference to the concept of military necessity can be found in three provisions of Article $28 \mathrm{D}$ on war crimes relating to appropriation or destruction of property, in particular: the grave breach of the Geneva Conventions of 'Extensive destruction and appropriation of property, not justified by military necessity and carried out unlawfully and wantonly' (28 (D)(a)(iv)) and the war crime of 'Destroying or seizing the enemy's property unless such destruction or seizure may be imperatively demanded by the necessities of war' (28D(b)(xiv) and $28 \mathrm{D}(\mathrm{e})$ (xii)). Thus, the concept of military necessity is relevant to determining whether these particular war crimes have been established but does not serve as a general defence to other crimes within the jurisdiction of the Malabo Protocol.

\section{Tu Quoque}

The defence of tu quoque, 'namely the defence of one Party to an armed conflict, or member thereof, to an allegation of the commission of atrocities, that the other Party has committed similar atrocities', has been consistently rejected in contemporary international criminal law. 259 This was made clear

${ }^{256}$ UNWCC, Digest of Laws and Cases, supra note 9, at 175. See also: United States Military Tribunal, Nuremberg, Trial of Wilhelm List and Others ('The Hostages Trial') in Law Reports of Trials of War Criminals, Vol. VIII (London: His Majesty's Stationery Office, 1949) at 66-9; United States Military Tribunal, Nuremberg, Trial of Wilhelm von Leeb and Thirteen Others ('The German High Command Trial') in Law Reports of Trials of War Criminals, Vol. XII (London: His Majesty's Stationery office, 1949) at 47-8 \& 93-4. See also ILC, 'Report of the Commission to the General Assembly on the work of its forty-eighth session', supra note 15, at 41 (reporting on the Draft Code of Crimes against the Peace and Security of Mankind).

257 See also Cryer et al, supra note 1, at 418; Bantekas, supra note 1, at 113.

${ }^{25} 5^{8}$ Katanga Trial Judgment, supra note 192, at para. 800.

259 Decision on Evidence of Good Character of the Accused and the Defence of Tu Quoque, Prosecutor v. Kupreškić et al. (IT-95-16), Trial Chamber, 17 February 1999 ('Kupreškić Decision'). See also Bantekas, supra note 1 at 121. 
by the Trial Chamber of the ICTY in the Kupreškić case. ${ }^{260}$ The Trial Chamber emphasized the irrelevance of reciprocity, particularly in relation to obligations found within international humanitarian law which have an absolute and non-derogable character. ${ }^{261}$ Accordingly, it concluded that the tu quoque defence has no place in contemporary international humanitarian law. ${ }^{2}{ }_{2}$ The rejection of this defence was affirmed by the ICTY Appeals Chamber in the Martić case. ${ }^{263}$ If African states wish to continue to apply the best practices of prior tribunals, this prospective defence might be one of the more prudent ones to omit.

\section{Reprisals}

As defined by the ICTY: 'In the law of armed conflict, belligerent reprisals are acts resorted to by one belligerent which would otherwise be unlawful, but which are rendered lawful by the fact that they are taken in response to a violation of that law committed by the other belligerent. Reprisals are therefore drastic and exceptional measures employed by one belligerent for the sole purpose of seeking compliance with the law of armed conflict by the opposite party. ${ }^{26} 4$ The question of reprisals as a legitimate defence was considered and left open throughout most of the drafting history of the Rome Statute. ${ }^{265}$ While not ultimately explicitly included in the final draft, the question may still arise through the 'window' left open in Article 31(3). Reprisals are only recognized under very strict conditions and there is a long list of prohibited objects of reprisals. ${ }^{266}$

The ICTY Trial Chamber in Martić delineated the cumulative conditions under which reprisals may be considered lawful, noting that such conditions

${ }^{260}$ Kupreškić Decision, ibid. See also Judgment, Prosecutor v. Kupreškić et al. (IT-95-16-T), Trial Chamber, 14 January 2000, ('Kupreškić Trial Judgment'), at para. 125 and 510-520.

${ }^{261}$ Kupreškić Trial Judgment, ibid., at para. 511.

${ }^{262}$ Ibid.

${ }^{263}$ Judgment, Prosecutor v. Milan Martić (IT-95-11-A), Appeals Chamber, 8 October 2008, ('Martić Appeal Judgment'), para. 111.

${ }^{264}$ Judgment, Prosecutor v. Milan Martić (IT-95-11-T), Trial Chamber I, 12 June 2007, para. 465 ('Martić Trial Judgment'). See also ICRC, Commentary on Art. 46 of Geneva Convention Relative to the Amelioration of the Condition of the Wounded and Sick in Armed Forces in the Field (2016), available online: www.icrc.org, para. 2729; Thiam, 'Fourth report on the draft Code', supra note 12, at para. 241; 'Final Report of the Commission of Experts Established Pursuant to Security Council Resolution 780 (1992),' Annex to Letter Dated 24 May 1994 from the Secretary-General to the President of the Security Council, 27 May 1994, S/1994/674, at para. 64 .

${ }_{265}$ Saland, supra note 23, at 209. 1996 Report of the Preparatory Committee, Vol. II, supra note 27, at 103; 'Report of the Ad Hoc Committee', supra note 17, at 2.

${ }^{266}$ See also Cryer et al., supra note 1, at 417-8. 
are 'well-established under customary law'. ${ }^{267}$ These conditions were further summarized by the Trial Chamber in Kupreškić:

[E]ven when considered lawful, reprisals are restricted by; (a) the principle whereby they must be a last resort in attempts to impose compliance by the adversary with legal standards (which entails, amongst other things, that they may be exercised only after a prior warning has been given which has failed to bring about the discontinuance of the adversary's crimes); (b) the obligation to take special precautions before implementing them (they may be taken only after a decision to this effect has been made at the highest political or military level; in other words they may not be decided by local commanders); (c) the principle of proportionality (which entails not only that the reprisals must not be excessive compared to the precedent unlawful act of warfare but also that they must stop as soon as that unlawful act has been discontinued) and; (d) 'elementary considerations of humanity'... ${ }^{268}$

The first treaty to protect certain persons from being the object of reprisal is the 1929 Convention Relative to the Treatment of Prisoners of War. ${ }^{269}$ All four 1949 Geneva Conventions contains prohibitions on reprisals against persons and property protected therein. ${ }^{270}$ These prohibitions are considered customary international law and would thus ordinarily be available in the context of international armed conflict. ${ }^{271}$ Extensive prohibitions against reprisals were

${ }^{267}$ Martić Trial Judgment, supra note 264, at paras 465-7. The ICTY in that case rejected Martićs argument that the shelling of Zagreb was a lawful reprisal. Martić Trial Judgment, at para. 468 ; Martić Appeal Judgment, supra note 263, at paras 263-7. See also Commentary on Article 46 of Geneva Convention Relative to the Amelioration of the Condition of the Wounded and Sick in Armed Forces in the Field (2016), available online at: www.icrc.org, para. 2732.

${ }^{268}$ Kupreškić Trial Judgment, supra note 260, at para. 535. See also Final Report of the Commission of Experts Established Pursuant to Security Council Resolution 780 (1992), Annex to Letter Dated 24 May 1994 from the Secretary-General to the President of the Security Council, 27 May 1994, S/1994/674, at para. 64; ICRC, Customary International Humanitarian Law, Rule 145, available online: www.icrc.org/customary-ihl/eng/docs/v1_rul_rule145.

${ }^{269}$ Convention Relative to the Treatment of Prisoners of War. Geneva, 27 July 1929, Art. 2. See Commentary on Art. 46 of Geneva Convention Relative to the Amelioration of the Condition of the Wounded and Sick in Armed Forces in the Field (2016), available online: www.icrc.org, at para. 2735 .

${ }^{270}$ Geneva Convention Relative to the Amelioration of the Condition of the Wounded and Sick in the Armed Forces in the Field, 12 August 1949, 75 U.N.T.S. 31, at Art. 46 (Geneva Convention I); Geneva Convention Relative to the Amelioration of the Condition of the Wounded, Sick and Shipwrecked Members of Armed Forces at Sea, 12 August 1949, 75 U.N.T.S. 85, at Art. 47 (Geneva Convention II); Geneva Convention Relative to the Treatment of Prisoners of War, 12 August 1949, 75 U.N.T.S. 135, at Art. 13 (Geneva Convention III); Geneva Convention Relative to the Protection of Civilian Persons in Time of War, 12 August 1949, 75 U.N.T.S. 287 , at Art. 33 (Geneva Convention IV).

${ }^{271}$ ICRC, Customary International Humanitarian Law, Rule 146, available online www.icrc.org/ customary-ihl/eng/docs/vi_rul_rule146. 
contained in Additional Protocol I to the Geneva Conventions of 1977 which prohibits reprisals against: wounded, sick, shipwrecked, and medical personnel; the civilian population or individual civilians; civilian objects; historical monuments, works of art or places of worship which constitute the cultural or spiritual heritage of peoples; objects indispensable to the survival of the civilian population; the natural environment; works or installations containing dangerous forces (dams, dykes and nuclear electrical generating stations). ${ }^{272}$ However, not all of these prohibitions in Additional Protocol I may yet be recognized as customary international law. ${ }^{273}$

While Additional Protocol II to the Geneva Conventions does not contain any provisions restricting reprisals, it has been suggested that this was because some states felt that reprisals had never been recognised in non-international armed conflicts and they did not want to open the door to such potential recognition. ${ }^{274}$ Thus, the ICRC asserts that as a matter of customary international law, '[p]arties to non-international armed conflicts do not have the right to resort to belligerent reprisals' and, further, that any other 'countermeasures against persons who do not or who have ceased to take a direct part in hostilities are prohibited. ${ }^{275}$ Similarly, the ICTY suggests that the prohibition against direct reprisals against civilians is to be inferred from the fundamental guarantees provided for in Article 4 of Additional Protocol II. ${ }^{276}$ In the Mbarushimana case, Pre-Trial Chamber I of the ICC affirmed generally that directing reprisals against the civilian population or individual civilians is prohibited. $^{277}$

Reprisals have not been widely used since World War II and are not considered to be particularly effective as a means of enforcing the other party to abide by the law. ${ }^{278}$ Reprisals derive from a time when there were limited other forms of deterrence for violations of international humanitarian law.

${ }^{272}$ Protocol Additional to the Geneva Conventions of 12 August 1949 and Relating to the Protection of Victims of International Armed Conflict, 8 June 1977, 1125 U.N.T.S. 3, at Arts 20 \& 51-6. See also Commentary of 1987 on Additional Protocol I, available online: www.icrc.org.

273 Cryer et al., supra note 1 , at 417 .

${ }^{274}$ ICRC, Customary International Humanitarian Law, Rule 148, available online www.icrc.org/ customary-ihl/eng/docs/vi_rul_ruleı48.

275 Ibid.

${ }^{276}$ Decision, Prosecutor v. Milan Martić (IT-95-11-R61) Trial Chamber, 8 March 1996, ('Martić Rule 61 Decision'), para. 16.

${ }^{277}$ Decision on the Confirmation of Charges, Prosecutor v. Callixte Mbarushimana (ICC-ol/ 04-01/10-465-Red), Pre-Trial Chamber I, 16 December 2001, at para. 143.

${ }^{27} 8$ Commentary on Art. 46 of Geneva Convention Relative to the Amelioration of the Condition of the Wounded and Sick in Armed Forces in the Field (2016), available online at: www.icrc.org, at para 2739. For discussion of reprisals in the post-World War II cases, see UNWCC, Digest of Laws and Cases, supra note 9, at 178-9. 
Given the recent proliferation of institutions for prosecutions of war crimes, the original purpose behind reprisals is arguably less relevant today. Thus, the ICTY has suggested that reprisals can 'no longer be justified' as a mechanism necessary for enforcing the laws of armed conflict. ${ }^{279}$ However, there is no indication that states are willing to close the door on the long-standing doctrine of reprisals. Regardless, pleas of reprisal as a defence have rarely been successful and are unlikely to be successful in most future cases given the very strict conditions that must be met and the long list of prohibited targets which may not be subjects of reprisals.

(a) Defensive operations The extent to which self-defence under Article 51 of the UN Charter and customary international law is relevant to determining whether or not an act of aggression has been committed is beyond the scope of this chapter. With respect to all other crimes within the scope of the Protocol, including war crimes, the fact that an individual committed those crimes while their troops were conducting a defensive military operation is not a defence for individual criminal responsibility. This is explicitly recognized in Article $31(1)(c)$ of the Rome Statute which explicitly states at the end of the paragraph on self-defence, defence of others and defence of property: "The fact that the person was involved in a defensive operation conducted by forces shall not in itself constitute a ground for excluding criminal responsibility under this subparagraph.'

This final phrase of Article 31(1)(c) was relied upon by an ICTY Trial Chamber in the Kordić and $\check{C} e r k e z$ case. ${ }^{280}$ The two accused, senior Bosnian Croat military and political figures, were charged with war crimes and crimes against humanity in relation to a campaign of persecution and ethnic cleansing and serious violations of international humanitarian law against the Bosnian Muslim population in the conflict in Central Bosnia in the early 199 os. $^{281}$ In response to many of the charges, the defence argued that the accused and the Bosnian Croats operating in the area were operating in selfdefence. The ICTY, with reference to this final sentence of Article 31(1)(c) of the Rome Statute, concluded that 'military operations in self-defence do not provide a justification for serious violations of international humanitarian law. ${ }^{282}$ The ICTY Appeals Chamber affirmed this in the Martic case, rejecting the defence's argument that the shelling of Zagreb was a lawful

\footnotetext{
${ }^{279}$ Kupreškić Trial Judgment, supra note 260, at para. 530.

${ }^{280}$ Kordić and Čerkez Trial Judgment, supra note 6.

${ }^{281}$ Ibid., at paras 4-6.

${ }^{282}$ Ibid., at para. 452 .
} 
military action conducted in self-defence. ${ }^{28} 3$ The Appeals Chamber reiterated that "whether an attack was ordered as pre-emptive, defensive or offensive is from a legal point of view irrelevant $[. .$.$] . The issue at hand is whether the way$ in which the military action was carried out was criminal or not. ${ }^{284}$

Similarly, other potential 'justifications' for the overall military operation have been rejected as defences. Surprisingly, in the SCSL's 'CDF Trial', one trial judge would have acquitted both accused of war crimes including murder, cruel treatment, pillage, and enlisting children under the age of 15 into armed forces on the basis of the argument that necessity and the doctrine of salus civis supreme lex est ('the safety of the state is the supreme law') formed defences for the accused. ${ }^{285}$ The availability of these defences, in Justice Thompson's reasoning, was based on the argument that the Civil Defence Forces (of which the accused were leaders) were fighting to reinstate the democratically elected government which was ousted by a coup. ${ }^{286}$ This approach was clearly rejected by the two other trial judges. ${ }^{287}$ In another SCSL case, Justice Thompson also opined that the fact that the accused were conducting a 'just war', i.e. 'the right to rebel against a corrupt and oppressive civilian government,' could constitute a ground for excluding criminal responsibility. ${ }^{288}$ The Appeals Chamber rejected this approach, observing that 'International humanitarian law specifically removes a party's political motive and the "justness" of a party's cause from consideration. ${ }^{289}$ Furthermore, the Appeals Chamber reiterated that 'rules of international humanitarian law apply equally to both sides of the conflict, irrespective of who is the "aggressor". 290

\section{H. Other Possible Defences?}

While Article 31(3) appeared to have been drafted primarily in response to the omission of the draft provision on defences for war crimes, it is not on its face

\footnotetext{
${ }_{283}$ Martić Appeal Judgment, supra note 263.

284 Ibid., at para. 268.

${ }^{28} 5$ CDF Trial Judgment - Dissenting Opinion of Judge Thompson, supra note 197, at paras 62-97.

286 Ibid., at para. 68.

${ }_{287}$ CDF Sentencing Judgment, supra note 198, at paras 70-81.

${ }^{288}$ Judgment, Prosecutor v. Sesay, Kallon and Gbao ('RUF Case') (SCSL-04-15-T), Trial Chamber I, 2 March 2009, Separate Concurring Opinion of Justice Bankole Thompson Filed Pursuant to Article 18 of the Statute, at paras 73-82. However, Justice Bankole Thompson did not find that the doctrine was not applicable in the facts of the case of the Revolutionary United Front.

${ }^{289}$ Judgment, Prosecutor v. Fofana and Kondewa (SCSL-04-14-A), Appeals Chamber, 28 May 2008, at para 530 ('CDF Appeal Judgment').

$29 \circ$ Ibid., at para. 247 .
} 
restricted in scope to this category of potential defences. It should be recalled that this provision was included because it was felt by the drafters that 'the Rome Statute could not possibly foresee all situations and that respect for the rights of the indicted made it necessary to have such a 'window'. ${ }^{291}$ Similarly, it is possible that other defences derived from national criminal laws may be plead as the jurisprudence at the African Court develops.

One issue worth considering is whether consent is a defence to certain crimes in international criminal law. In particular, this may be relevant to crimes involving the recruitment of child soldiers and to sexual violence crimes, in particular rape. ${ }^{292}$ Other defences such as procedural bars to prosecution should also be considered.

\section{Consent and Recruitment of Child Soldiers}

Both the ICC and the SCSL, the two courts which have convicted individuals for crimes involving the enlistment, conscription, and use of child soldiers, have explicitly rejected that consent is a defence to the recruitment of a child under the age of $15 .{ }^{293}$ In reaching this conclusion, the ICC Trial Chamber relied on testimony from an expert witness who submitted that from a psychological point of view children cannot give "informed" consent when joining an armed group, because they have limited understanding of their voices; they do not control or fully comprehend the structures and forces they are dealing with; and they have inadequate knowledge and understanding of the short- and long-term consequences of their actions. ${ }^{294}$ Similarly, the SCSL stated that "where a child under the age of 15 years is allowed to voluntarily join an armed force or group, his or her consent is not a valid defence. ${ }^{295}$ Interestingly, in contrast to the Rome Statute which includes war crimes of conscripting, enlisting and using children under fifteen years of age, the Malabo Protocol raises this age limit and criminalizes 'conscripting or enlisting children under the age of eighteen years [...] or using them to participate actively in hostilities. ${ }^{296}$ This increase in age is reflective of the provisions of the Optional Protocol to the Convention on the Rights of the

\footnotetext{
${ }^{291}$ Saland, supra note 23, at 209.

${ }^{292}$ Cryer et al, supra note 1 , at $416-17$.

${ }^{293}$ Lubanga Trial Judgment, supra note 21, at para. 617; SCSL, CDF Appeal Judgment, supra note 289 , at para. 140 .

${ }^{294}$ Lubanga Trial Judgment, ibid., at para. 610.

295 CDF Appeal Judgment, supra note 289, at para. 140.

${ }^{296}$ Art. $28 \mathrm{D}(\mathrm{b})(\mathrm{xxvii})$ and Art. $28 \mathrm{D}(\mathrm{e})$ (vii).
} 
Child. ${ }^{297}$ However, Mark Drumbl's recent book presents a more complex picture of the realities of child soldiers and challenges the failure to acknowledge the agency of children, which might militate in favour of a less paternalistic approach to the notion of consent. ${ }^{298}$ This argument deserves further consideration in the context of the cultural norms on the African continent, in particular with respect to adolescents as they approach the higher age limit included in the Malabo Protocol.

\section{Rape and Consent}

Consent may also be framed as a potential 'defence' to allegations of rape. Rape is included as a crime against humanity in Article $28 \mathrm{C}(1)(\mathrm{e})$ of the Protocol, as a war crime in Article 28D (b)(xxiii) and (e)(vi), and as an act of genocide in Article $28 \mathrm{~B}(\mathrm{f})$ of the Protocol. Rape is not defined in the Protocol. The ICTY Appeals Chamber defined rape as: 'sexual penetration ... where such sexual penetration occurs without the consent of the victim. ${ }^{299}$ However, the Appeals Chamber noted that the circumstances ... that prevail in most cases charged as either war crimes or crimes against humanity will be almost universally coercive. That is to say, true consent will not be possible. ${ }^{300}$ The Elements of Crimes of the Rome Statute define the crime against humanity of rape as penetration when: "The invasion was committed by force, or by threat or force or coercion, such as that caused by fear of violence, duress, detention, psychological oppression or abuse of power, against such person or another person, or by taking advantage of a coercive environment, or the invasion was committed against a person incapable of giving genuine consent.' Thus, the absence of consent is not an element of rape and, accordingly, cannot be raised in defence.

\section{Alibi}

The Rules of Procedure and Evidence of the ICTY and ICTR both reference a particular procedural obligation on the accused to notify the Prosecutor

297 Art. 1 of the Optional Protocol to the Convention on the Rights of the Child on the involvement of children in armed conflict, 2173 U.N.T.S. 222, 25 May 2000 (New York), provides that 'States Parties shall take all feasible measures to ensure that members of their armed forces who have not attained the age of 18 years do not take a direct part in hostilities.' Whereas, Art. 38(2) of the Convention on the Rights of the Child, 1577 U.N.T.S., 20 November 1989 (New York), only provides that 'States Parties shall take all feasible measures to ensure that persons who have not attained the age of fifteen years do not take a direct part in hostilities.' [Emphasis added]

${ }^{29} 8$ M. A. Drumbl, Reimagining Child Soldiers in International Law and Policy (Oxford: Oxford University Press, 2012).

299 Judgment, Prosecutor v. Kunarac et al. (IT-96-23\&IT-96-23/1-A), 12 June 2002, at paras 127-8.

300 Ibid., at para. 130. 
should it seek to raise 'the defence of alibi. ${ }^{301}$ The ICC Rules of Procedure place a similar disclosure obligation on the accused but do not refer to alibi explicitly as a 'defence'. ${ }^{302}$ This language used by the ICC better reflects the fact that alibi is not a true defence but, rather, merely amounts to a factual challenge to the Prosecution's assertion that this particular accused perpetrated the given crime. The ICTY Appeals Chamber itself criticized the wording of that Tribunal's Rules of Procedure and Evidence, as it stated: 'It is a common misuse of the word to describe an alibi as a 'defence'. If a defendant raises an alibi, he is merely denying that he was in a position to commit the crime with which he is charged. That is not a defence in its true sense at all. ${ }^{303}$ Thus, while it may be incumbent upon the African Court to consider a similar disclosure obligation upon the accused when drafting its own rules of procedure and evidence, nothing further need be discussed about an argument of alibi here.

\section{Non Bis In Idem}

Article $46 \mathrm{I}$ of the Malabo Protocol includes the principle Non bis in idem ("not twice in the same'). Also referred to as the prohibition against 'double jeopardy' in some domestic jurisdictions, this principle prevents an individuals from being tried more than once for the same conduct. ${ }^{304}$ It represents a general principle of law and can be found in the statutes of other international courts including in Article 20 of the Rome Statute and Article 10 of the ICTY Statute as well as in human rights instruments. ${ }^{305}$ This prohibition, as defined in the Malabo Protocol, can be broken down into two components. First, no individual who has been convicted or acquitted by the African Court can be re-tried for the same conduct at the African Court. Secondly, no individual who has been tried by any other court can be prosecuted for the same conduct for the African Court provided that the initial trial was genuine. This could

${ }^{301}$ ICTY Rules of Procedure and Evidence, supra note 51, at Rule 67(B)(i)(a); ICTR Rules of Procedure and Evidence, Adopted on 29 June 1995, as amended, Rule 67(A)(ii)(a);

${ }^{\circ 02}$ The ICC Rules and Procedure refer to such an obligation if the defence intends to 'Raise the existence of an alibi.' Supra note 8, at Rule 79(1)(a).

303 Čelebić Appeals Judgment, supra note 32, at para. 581. [Emphasis original]

${ }^{304}$ Immi Tallgren and Astrid Reisinger Coracini, 'Article 20' in Otto Triffterer (ed.), Commentary on the Rome Statute of the International Criminal Court, (2nd edn., Munich: C.H. Beck, 2008) 669, at 670. This chapter of the Commentary provides a helpful general overview and comprehensive discussion of the principle of ne bis in idem.

305 For discussion of this provision in international human rights law see Tallgren and Coracini, ibid., at $674-7$. 
include a trial before a national court or before another international court such as the ICC. In particular, paragraph 2 of the provision states:

Except in exceptional circumstances, no person who has been tried by another court for conduct proscribed under Article 28A of this Statute shall be tried by the Court with respect to the same conduct unless the proceedings in the other Court:

(a) Were for the purpose of shielding the person concerned from criminal responsibility for crimes within the jurisdiction of the Court;

(b) Otherwise were not conducted independently or impartially in accordance with the norms of due process recognized by international law and were conducted in a manner which, in the circumstances, was inconsistent with an intent to bring the person concerned to justice.

In essence, if a trial has been completed before any other court, the judgment of that other court is a bar to prosecution at the African Court except in the case of a sham proceeding, in particular a proceeding designed to shield the accused from genuine prosecution. The inclusion of the phrase, 'except in exceptional circumstances', at the start of this provision (which is a departure from Article 20 of the Rome Statute on which this provision appears to be based) is an unfortunately vague addition. In the interest of fairness to the accused, such exceptional circumstances should be limited to the particular exceptions set out within the paragraph itself (i.e. non-genuine proceedings). Finally, it is important to note that this provision protects an individual being tried twice for the same 'conduct.' Thus, it is not necessary that the particular crime charged be the same.

\section{Youth}

Article 46D of the Malabo Protocol limits the personal jurisdiction of the African Court to exclude individuals who committed crimes while under the age of eighteen. This age limit for prosecutions aligns with the approach taken in Article 26 of the Rome Statute of the ICC. The drafting history of the Rome Statute demonstrates that it was difficult for states to agree on the age of criminal responsibility which ranged in domestic jurisdictions from 7 to $21 .^{306}$ Thus, it is helpful that the Malabo Protocol explicitly defines the age limit for prosecutions before the African Court. The Malabo Protocol also follows the approach of the Rome Statute which frames the issue as a jurisdictional exclusion. This approach was adopted in Rome because '[i]t

306 Saland, supra note 23 , at 201. 
could then be argued that the provision in no way prejudiced whatever age of responsibility existed in the national system, and it could not be seen as condoning offenses by minors. ${ }^{307}$ Nonetheless, as Eser observes, this can be considered a ground for excluding criminal responsibility because the essential reason behind this [provision] is the lack of criminal responsibility under a certain age'..$^{\circ 08}$

\section{Statutes of Limitations}

The final paragraph of Article 28A, which enumerates all of the crimes within the jurisdiction of the African Court, declares that no statute of limitations shall apply to any of these crimes. ${ }^{309}$ This provision follows the approach taken in Article 29 of the Rome Statute. It has been suggested that such a provision is unnecessary because silence, i.e. the absence of any specified time limitations on cases, would have reached the same result. ${ }^{310}$ However, as Schabas observes in his commentary on the equivalent provision in the Rome Statute, such a provision 'operates as an answer to any argument from a State Party whereby extradition might be refused because of a statutory limitation in its own domestic penal code. ${ }^{311}$ Furthermore, it is a helpful clarification to specify that there is no statute of limitations to any of the crimes within the jurisdiction of the Court since the subject matter jurisdiction of the Court extends far beyond the core crimes included in the ICC's jurisdiction or are referred to in the Convention on the Non-Applicability of Statutory Limitations to War Crimes and Crimes Against Humanity. ${ }^{312}$

\section{CONCLUSION}

The Malabo Protocol's predominant silence on the issue of defences is unfortunate. Questions of defences to criminal responsibility will certainly be a challenging legal issue faced by the African Court. The limited

\footnotetext{
307 Ibid.

${ }^{308}$ Eser, supra note 18 , at 868.

309 Art. 28A(3).

${ }^{310}$ William A. Schabas, 'Article 29' in Otto Triffterer (ed.), Commentary on the Rome Statute of the International Criminal Court, (2nd edn., Munich: C.H. Beck, 2008) 845 at 846, 847 .

${ }^{311}$ Ibid., at 848 .

${ }^{312} 754$ U.N.T.S. 73, 26 November 1968, New York. There are only 55 States Party to this Convention, but some courts have found the prohibition on statutory limitations for some international crimes to form part of customary international law. Schabas, supra note 310, at 846; Cryer et al., supra note 1 , at 83-4.
} 
jurisprudence from earlier international criminal tribunals demonstrates how difficult it can be to discern general principles of law when diverging approaches are taken amongst the different major legal systems of the world. Furthermore, general principles of law simply that - principles - and, thus, lack the specificity to answer all questions on the definition of certain defences.

Nonetheless, the Court will have to identify and define which defences are applicable. In doing so, the Court will face a number of issues. First, the Court will have to consider what sources of law it will consider. In particular, will the Court turn to domestic law as a default if no general principle of law can be found? The Court will also, of course, face substantive issues with respect to the recognition and definition of certain defences. Will intoxication be accepted as a defence to serious crimes within the Court's jurisdiction? Are any crimes excluded from the application of the defence of duress or necessity? Is defence of property recognized as a ground for excluding criminal responsibility in light of the seriousness of the crimes within the Court's jurisdiction? Finally, the Court will also face many procedural and evidentiary issues. The Court will have to determine whether any burden lies on the accused to establish certain defences. Additionally, evidentiary and procedural rules relating to defences should be considered when Rules of Procedure and Evidence are drafted including rules relating to disclosure obligations on accused in raising such defences.

Despite the absence of a comprehensive provision in the Malabo Protocol, defences cannot be ignored. Defences form a necessary and integral part of any criminal law, no matter how serious the offences within the jurisdiction of the Court. Fortunately, there is a growing body of resources upon which the African Court can draw to determine which defences have been recognized in international criminal law or, conversely, which defences have been explicitly rejected. Significantly, the Court can turn to the first codification of defences in international criminal law in the Rome Statute for guidance. The difficulty involved in negotiating this provision of the Rome Statute yet again demonstrates the divergence amongst domestic jurisdictions on many questions relating to defences. Thus, the fact that compromises were reached and a provision was adopted will prove helpful for the African Court, particularly in light of the fact that Rome Statute has been ratified or acceded to by 123 states including many African countries. Further guidance may also be provided by the jurisprudence of the ICTY as well as the work of the UNWCC and the ILC. Ultimately, the Court will have to determine which defences are applicable and how they are defined as the arguments are put before it by accused, with reference, in particular, 
to customary international law and general principles of law. The Court may also want to consider the extent, if any, to which national laws may be resorted to in order to fill any lacuna in the law. Here the role of African state practice in accepting, or rejecting particular defences, would be helpful to consider. However, should the opportunity present itself to revisit and amend the Malabo Protocol, including a comprehensive provision on defences should be near the top of the agenda. 